\title{
Taxonomy, ecology and biogeographical trends of dominant benthic foraminifera species from an Atlantic-Mediterranean estuary (the Guadiana, southeast Portugal)
}

\author{
Sarita Graça Camacho, Delminda Maria de Jesus Moura, \\ Simon Connor, David B Scott, and Tomasz Boski
}

\begin{abstract}
This study analyses the taxonomy, ecology and biogeography of the species of benthic foraminifera living on the intertidal margins of the Guadiana Estuary (SE Portugal, SW Spain). Of the 54 taxa identified during sampling campaigns in winter and summer, 49 are systematically listed and illustrated by scanning electron microscope (SEM) photographs. Ammonia spp. were the most ubiquitous calcareous taxa in both seasons. Morphological analysis and SEM images suggested three distinct morphotypes of the genus Ammonia, two of which proved to be Ammonia aberdoveyensis on the basis of partial rRNA analyses. Jadammina macrescens and Miliammina fusca were the most ubiquitous agglutinated taxa in the estuary. Jadammina macrescens dominates the upper-marsh zones almost exclusively, occurring at very high densities. Ammonia spp. are the most abundant in the low-marsh and tidal-flats of the lower reaches of the Guadiana Estuary, but are widespread throughout the estuary, especially during summer when environmental conditions favor their proliferation. Miliammina fusca dominates the sparsely vegetated low-marsh and tidal-flat zones of the upper reaches, where it is associated with calcareous species. Due to its geographical position, the Guadiana system shares characteristics of both Atlantic and Mediterranean estuaries. This is reflected in the foraminiferal assemblages, with a dominance of thermophilous species and an ecological zonation typical of the Mediterranean climatic zone.
\end{abstract}

Sarita Graça Camacho. Center of Environmental and Marine Research (CIMA), Faculdade de Ciências e Tecnologia, Universidade do Algarve, Campus de Gambelas, 8005-139 Faro, Portugal scamacho@ualg.pt Delminda Maria de Jesus Moura. CIMA, Faculdade de Ciências e Tecnologia, Universidade do Algarve, Campus de Gambelas, 8005-139 Faro, Portugal. dmoura@ualg.pt

Simon Connor. School of Earth, Atmosphere and Environment, Faculty of Science, Monash University, Clayton 3800, Australia. Simon.Connor@monash.edu

David B Scott. Centre for Environmental and Marine Geology, Department of Earth Sciences, Dalhousie University, Halifax, Nova Scotia, Canada B3H 4J1. dbscott@dal.ca 
Tomasz Boski. CIMA, Faculdade de Ciências e Tecnologia, Universidade do Algarve, Campus de Gambelas, 8005-139 Faro, Portugal. tboski@ualg.pt;

Keywords: benthic foraminifera; taxonomy; biogeography; ecological zonation; genetic analysis; Guadiana Estuary

\section{INTRODUCTION}

Foraminifera are single-celled organisms that possess a hard test, which often remains in the sediment where it may fossilize. Foraminifera were first described and illustrated in the sixteenth century but only studied systematically in the nineteenth century following the remarkable voyage of HMS Challenger (Lowe and Walker, 1997). Their usefulness in stratigraphy was gradually realized, and they attained a fundamental role in applied science as stratigraphical index fossils (Albani et al., 2001). Widely used in petroleum assessment, foraminifera are also important in paleoclimatic, paleosea-level, paleo-depth and paleoceanographic studies and in age determinations using oxygen isotopes (Albani et al., 2001). Stratigraphically, foraminifera appear in the Early Cambrian at about the same time as the metazoans with skeletons (Pawlowski et al., 2003), diversifying into thousands of species adapted to all marine and coastal environments, from the most superficial to the greatest oceanic depths (Scott et al., 2001). Currently, around 6800 species of foraminifera are estimated to exist (Hayward et al., 2014).

Accurate taxonomy is essential for classifying the fossil species and to create reliable environmental analogies. The test is the most commonly studied element of foraminifera, as classification relies essentially on morphological characteristics (Debenay et al., 1996). However, the taxonomic value of those characteristics is questionable due to the influence of environmental factors on the morphology of foraminiferal tests, which makes the distinction between ecophenotypes and species difficult (Holzmann and Pawlowski, 1997). These difficulties are particularly problematic in the case of species of cosmopolitan distribution and with high morphological variability, such as the genera Ammonia (Hayward et al., 2004) and Elphidium (Feyling-Hanssen, 1972; Miller et al., 1982). The high morphological variability of Ammonia, for instance, rendered its status uncertain and controversial (Pawlowski et al., 1995; Holzmann and Pawlowski, 1997; Debenay et al., 1998a; Holzmann et al., 1998; Langer and Leppig, 2000) until molecular studies were used to better under- stand its taxonomy (Hayward et al., 2004). More than 40 species and subspecies (or varieties) of Ammonia have been described worldwide, and at least 30 species were expected to be recognizable by molecular techniques (Hayward et al., 2004). The application of molecular techniques has brought new insights into foraminiferal taxonomy. Pawlowski et al. (1994) demonstrated that the analysis of RNA ribosomal sequences can be applied in the identification of foraminiferal species, providing a new taxonomic criterion, independent of the morphological characteristics of the test. Molecular analysis also enables an evaluation of the ecological significance of various morphological characteristics and the determination of intraspecific morphological variability (Pawlowski et al., 1994). Since 1994, molecular techniques improved and became more accessible. Thus, is expected that taxonomic descriptions of new and/or modern species of foraminifera with controversial classifications include genetic data in addition to morphologic information.

Along with taxonomy, it is essential to study the living assemblages, their main features, life cycles and ecological tolerances in order to perform consistent and reliable paleo-interpretations (Calonge et al., 2001). In Portugal, most ecological studies based on estuarine foraminifera have been performed in order to establish modern databases through which fossil foraminiferal assemblages can be compared and interpreted (e.g., Fatela and Silva, 1990; Cearreta et al., 2002, 2007; Andrade et al., 2004; Moreno et al., 2005; Fatela et al., 2009; Leorri et al., 2010). Nevertheless, the resulting taxonomic data are very limited, with little systematic study and no molecular analysis. Recently, the seasonal and spatial patterns of live benthic foraminifera in intertidal margins of the Guadiana Estuary were studied (Camacho et al., 2015). That analysis lacked detailed taxonomical information and genetic data. In order to address these knowledge gaps, this study presents a photographic and systematic compendium of almost all species found in the estuary and provides preliminary genetic information on two of the most important taxa. These data, along with the ecology and bio- 
geography of the main species, are expected to complement the previous study by Camacho et al. (2015) and contribute to a more robust taxonomic basis for foraminiferal identification.

\section{Study area}

From its headwaters located in Lagoas de Ruidera (1700 m altitude) in Spain, the Guadiana River runs $810 \mathrm{~km}$ until it reaches the Atlantic Ocean between the Portuguese town of Vila Real de Santo António and Spanish town of Ayamonte (Figure 1). The terminal 200-km stretch of the river follows a north-south course and sets the national border between the two countries (M.A., 1999). The estuarine system is characterized by semidiurnal mesotidal regime (Morales et al., 2006), with tidal influence, in a physical sense, extending 44 km upstream to Pomarão (Barros and Candeias, 1998). The mean tidal range at the river mouth is approximately $2 \mathrm{~m}$, reaching $3.4 \mathrm{~m}$ during spring tides (I.H., 2011). Its basin has Mediterranean climatic characteristics, with hot, dry summers, strong insolation and high evapotranspiration. The winters are relatively cold and continental in the upper reaches of the river and become milder downstream (M.A., 1999).

The Estuary includes a series of habitats of high ecological value, such as a rich wetland zone (saltmarshes, salt pans, tidal creeks and ponds), intertidal flats, barrier islands and sandy spits. The wetland is noteworthy for its halophytic saltmarsh communities (Ramsar, 2013), which carry out an essential role in the functioning and maintenance of a healthy ecosystem (Simonson, 2007) and have earned the estuary its status as a Natural Reserve in the Portuguese conservation network (ICNB, 2007).

\section{METHODOLOGY}

\section{Sampling and Processing}

During the two most contrasting seasons, i.e., winter (February and March) and summer (August), of the year 2010, 49 samples of the top 1 $\mathrm{cm}$ of surface sediment of the river's intertidal margins were collected in order to cover the environmental range of living benthic foraminiferal assemblages in the Guadiana Estuary. The sampling extended over $27 \mathrm{~km}$, from the most upstream site located at Laranjeiras (LAR site) to the mouth of the river at Lagoa (LG site), covering the entire salinity gradient of the estuary (see Table 1, Appendix). In total, 11 sites were sampled, with the majority located on the right bank of the river
(Figure 1). In the middle and upper estuary, only one sample was collected per site due to the absence of saltmarsh zonation. In the lower estuary, where the environmental zonation is wellmarked due to a more pronounced tidal range, three to four samples were collected along topographic profiles at each site, usually running perpendicular to the river course. These transects were placed according to the vertical zonation of halophytic vegetation, with the aim of sampling the distinct pedomorphic units, from unvegetated mudflats (permanently wet) to the higher levels of the marsh. Topographic profiles were surveyed in detail using a differential Global Positioning System (d-GPS) and a Trimble 5800 mobile unit (a Nikon DTM 310 Total Station was employed in places without a radio signal). Elevation was measured in relation to mean sea level (MSL) (datum 73). Samples were divided into upper marsh (collected at 1-2 meters above MSL), lower marsh (01 meters above MSL) and mud zone ( $-1-0$ meters in relation to $\mathrm{MSL}$ ). The salinity gradient was divided in three sectors: lower, middle and upper estuary (Figure 1) according to Boski et al. (2006).

At each sampling point, two pseudoreplicates were collected (replicates of the same sample) (Hurlbert, 1984) with the aim of avoiding the effect of patchiness (Debenay et al., 2006), which is the non-uniform distribution trend of benthic foraminiferal assemblages in shallow, marginal environments usually caused by asynchronous reproduction pulses (Buzas et al., 2002). Each pseudoreplicate was collected using small PVC cores of $15-\mathrm{cm}$ length and 5-cm diameter, keeping the first $\mathrm{cm}$ of sediment $(19.6 \mathrm{cc})$ for foraminiferal analysis. Samples for foraminifera, sediment texture and elemental composition analysis were collected during ebb time. Physico-chemical parameters of river water (salinity, temperature and dissolved oxygen) and the sediment $(\mathrm{pH})$ were also measured (Camacho et al., 2014).

In the laboratory, $20 \mathrm{cc}$ aliquots of the samples were separated and kept in a mixture of Rose Bengal and ethanol $(2 \mathrm{~g} / \mathrm{l})$ for two days. After this period, samples were wet-sieved in a column of two sieves: $63 \mu \mathrm{m}$ to retain the fraction for analysis and $500 \mu \mathrm{m}$ to remove large organic debris. Samples with high organic content and with high number of foraminifera, both calcareous and agglutinated, were split into smaller aliquots using a wet splitter (Scott and Hermelin, 1993). Samples with few individuals, or with calcareous tests only, were dried and sprinkled into carbon tetrachloride to float off the tests. Whenever possible, 100 to 300 


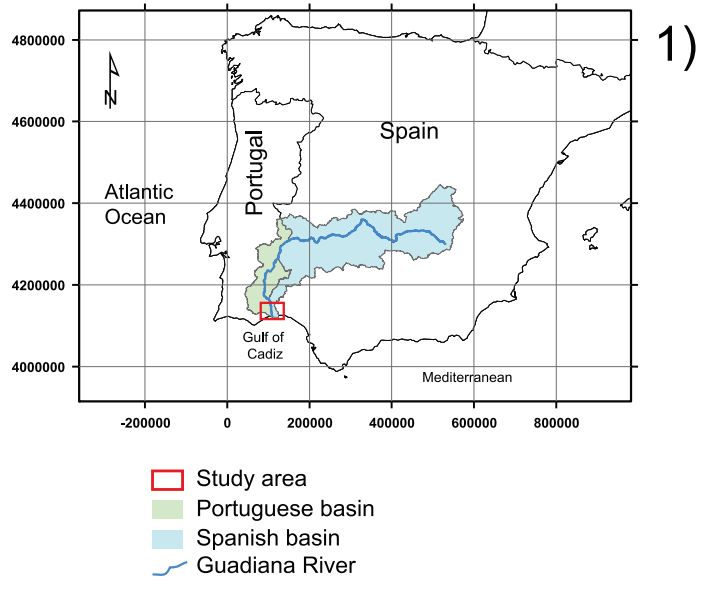

1)

\section{Legend}

- Sampling transects

- Sampling points

Sea, river and channels

\section{Land use types}

\begin{tabular}{l} 
Urban infrastructures \\
Beach sand \\
Sinewood \\
Salt marsh and river alluvial margins \\
\hline Other land use type
\end{tabular}

\section{Sites}

LAR - Laranjeiras

FO - Foz de Odeleite

Aouro - Almada d'Ouro

FB - Foz do Beliche

PI - Ponte Internacional

LEZ - Lezíria

SCM - Sapal de Castro Marim

VRSA - Vila Real de Santo António

EE - Espanha ETAR

E - Espanha

LG - Lagoa
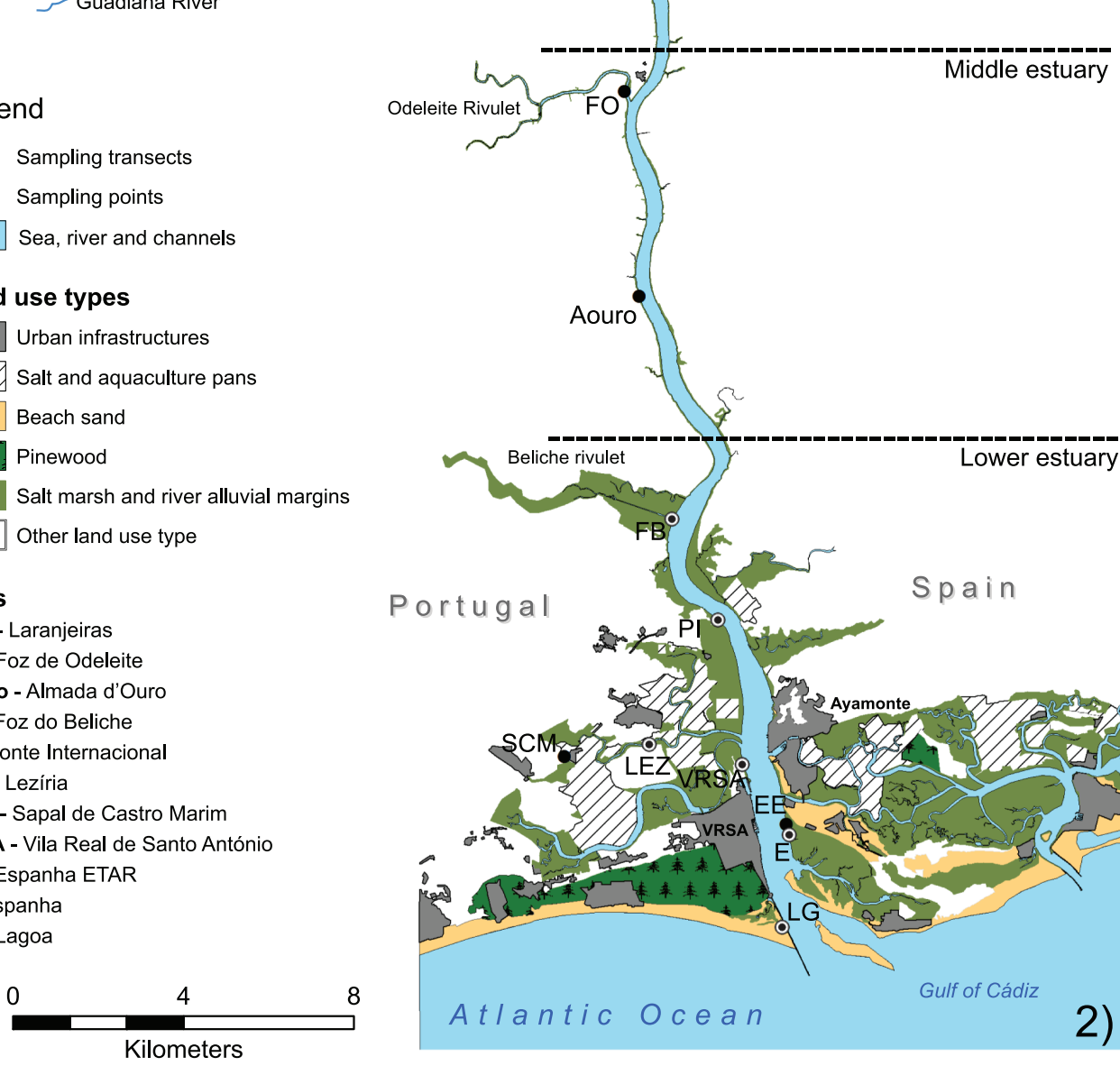

Upper estuary
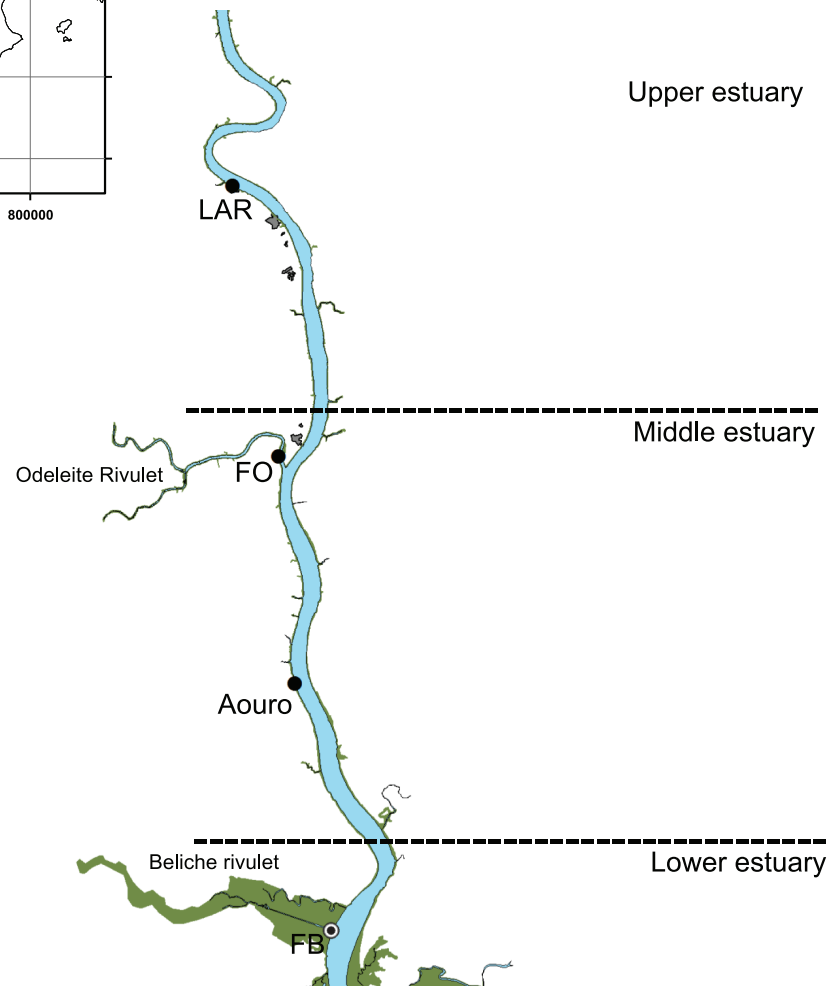

Portugal

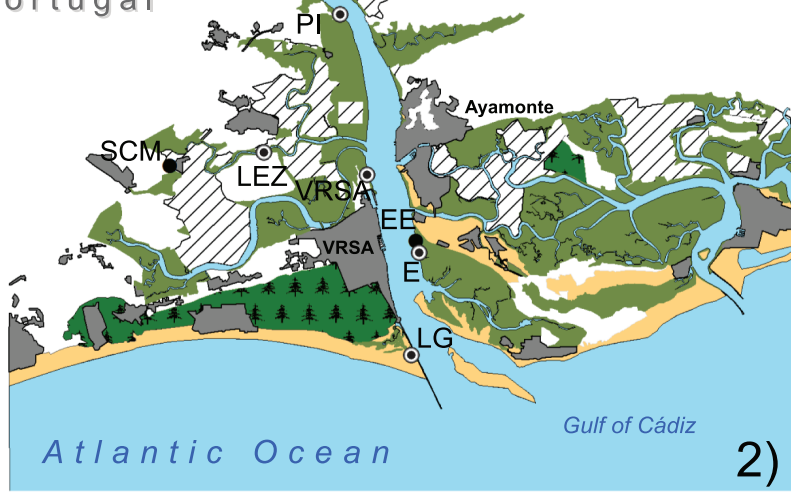

FIGURE 1. Location of the study area; 1) Geographical context of the Guadiana River basin in the Iberian Peninsula (Europe). Adapted from chguadiana.es (2012). Coordinate system: Datum ETRS89 UTM Zone 30N; 2) Study area: Map of the Guadiana Estuary with site locations.

living individuals were counted. Due to low numbers of stained individuals in some samples, an exceptional threshold of 48 living individuals was adopted for the purpose of statistical significance (see details in Camacho et al., 2015). Samples with fewer than 48 living individuals were not analyzed statistically (in grey in Tables 2 and 3, Appendix).

\section{Identification and Classification}

Forty-nine species were photographed using a scanning electron microscope (SEM), model JEOL JSM-5410, based at Huelva University and are presented in plates (Figures 2, 3, 4, 5).

Several guides were used for identification, especially Colom (1974), Loeblich and Tappan 


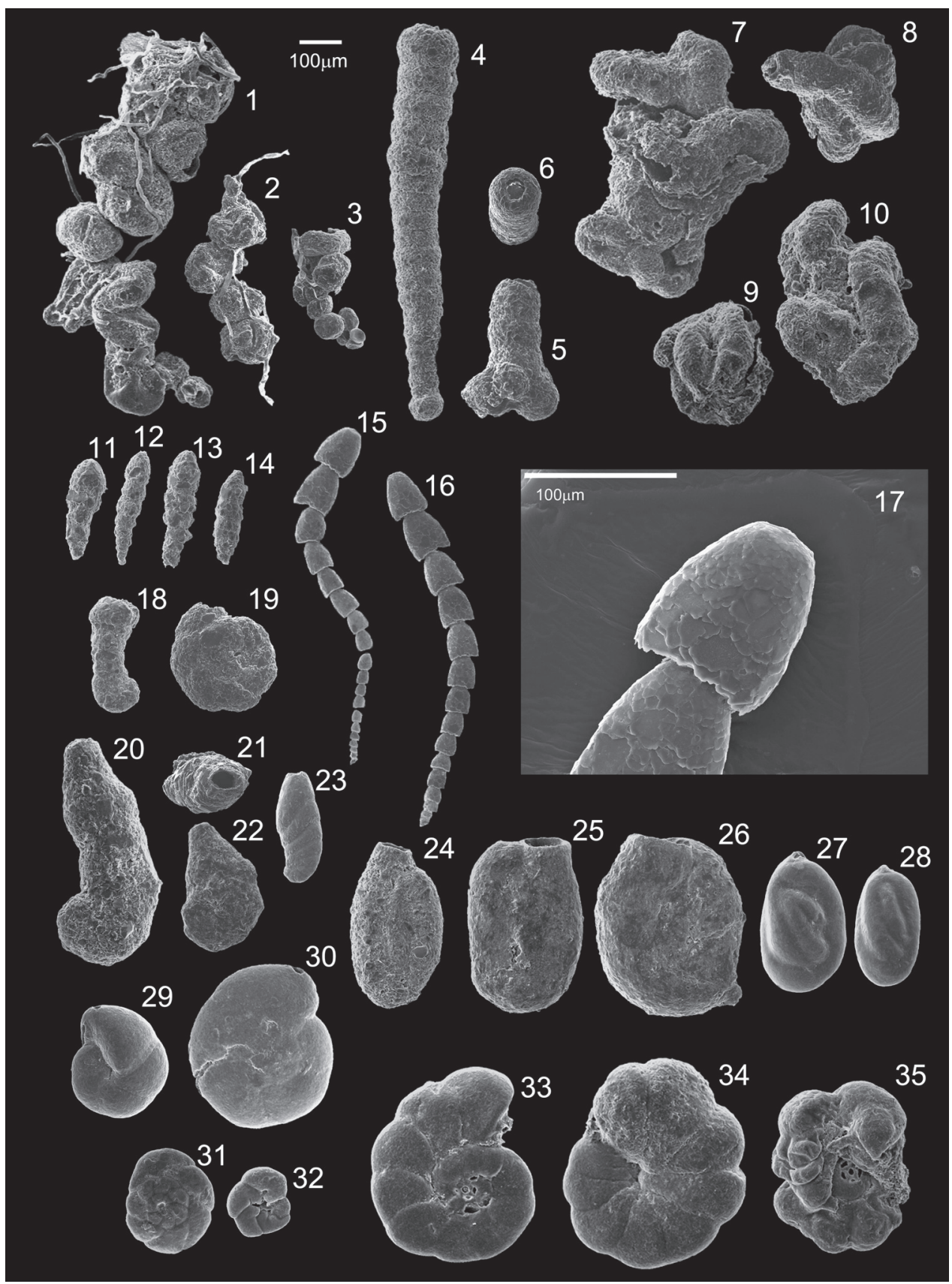

FIGURE 2. Scanning electron micrographs of the foraminifera specimens. Scale bar equals $100 \mu \mathrm{m}$. 1-3- Three different specimens of Polysaccammina ipohalina Scott, 1976b, illustrating the differences in size and form. In all specimens it is possible to see attached organic matter; 4-5- Polysaccammina hyperhalina Medioli, Scott, and Petrucci, 1983. 4- complete specimen of $P$. hyperhalina; 5- aperture view; 6- specimen with several side branches; 7-10- different sized specimens of Ammovertellina sp.; 11-14- various specimens of Reophax nana Rhumbler, 1913; 15-17Leptohalysis scottii (Chaster, 1892); 15 and 16- side view of two complete specimens; 17- detail on the agglutination of the last chamber; 18- complete specimen of Ammobaculites exiguus Cushman and Brönnimann, 1948b; 19Ammobaculites sp. with the uncoiled portion broken; 20-22- Ammotium salsum (Cushman and Brönnimann, 1948a); 20- best specimen; 21- smaller specimen; 22- aperture detail; 23- Ammotium sp.; 24-26- different specimens of Miliammina fusca (Brady, 1870); 27-28- Miliammina obliqua Heron-Allen and Earland, 1930; 27- view of the interio-marginal arch of the aperture; 29-30- Arenoparrella mexicana (Kornfeld, 1931); 29- ventral side with view to main aperture and supplementary apertures; 30- dorsal side with view to supplementary apertures; 31-32- Deuterammina eddystonensis Brönnimann and Whittaker, 1990; 31- dorsal view; 32- ventral view; 33-35- Jadammina macrescens (Brady, 1870); 33- dorsal view; 34- ventral view; 35- dorsal view of a deformed test. 


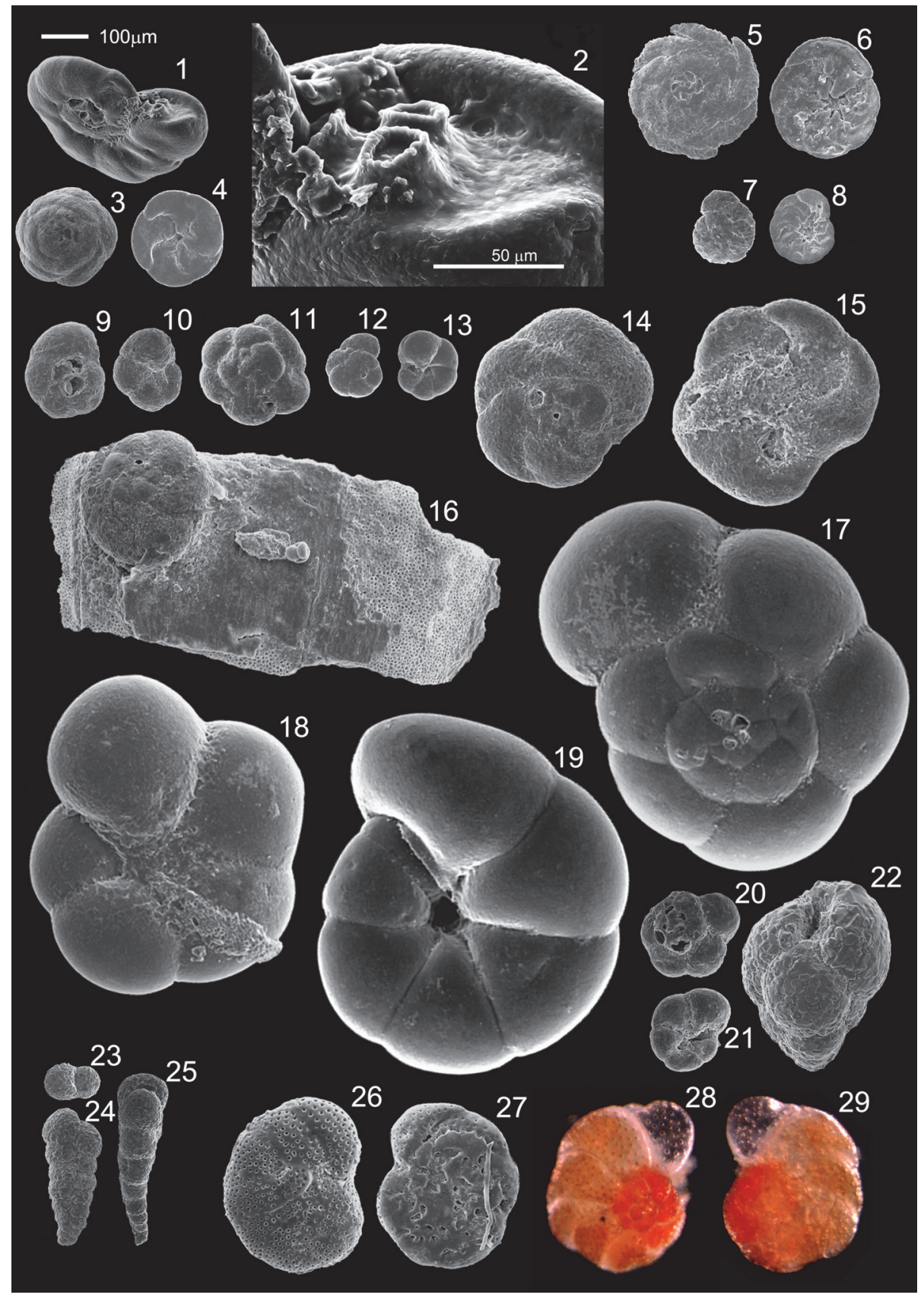

FIGURE 3. Scanning electron and light microscope micrographs of the foraminifera specimens. Scale bar equals $100 \mu \mathrm{m}$ except where noted otherwhise; 1-2- Jadammina macrescens (Brady, 1870); 1- supplementary apertures view; 2- detail of supplementary apertures (scale bar $=50 \mu \mathrm{m}$ ); 3-4- Lepidodeuterammina plymouthensis Brönnimann and Whittaker, 1990; 3- dorsal view; 4- ventral view; 5-8- Lepidodeuterammina ochracea (Williamson, 1858); 5- dorsal view; 6- ventral view; 7- dorsal view of a smaller specimen; 8- ventral view of a smaller specimen; 9-10Portatrochammina sp.; 9- dorsal view; 10- ventral view; 11-13- Siphotrochammina sp.; 11- dorsal side with inter-cameral foramen view; 12- dorsal view of a smaller specimen, also with inter-cameral foramen; 13- ventral view of a smaller specimen; 14-16- Tiphotrocha comprimata Saunders, 1957; 14- dorsal view; 15- ventral view; 16- individual strongly attached to a sea-grass leaf; detail of a Pinus pollen grain at the center of the leaf; 17-21- Trochammina inflata (Montagu, 1808); 17- dorsal view; 18- ventral view; 19- ventral view with umbilical tube detail; 20- microspheric form dorsal view; 21- microspheric form ventral view; 22- Eggerelloides scaber (Williamson, 1858); 23-25Textularia earlandi Parker, 1952; 23- apertural view; 24- lateral view; 25- profile view with aperture in detail; 26-29Discorinopsis aguayoi (Bermúdez, 1935); 26- scanning electron dorsal view; 27- scanning electron ventral view; 28light microscope dorsal view; 29- light microscope ventral view. 


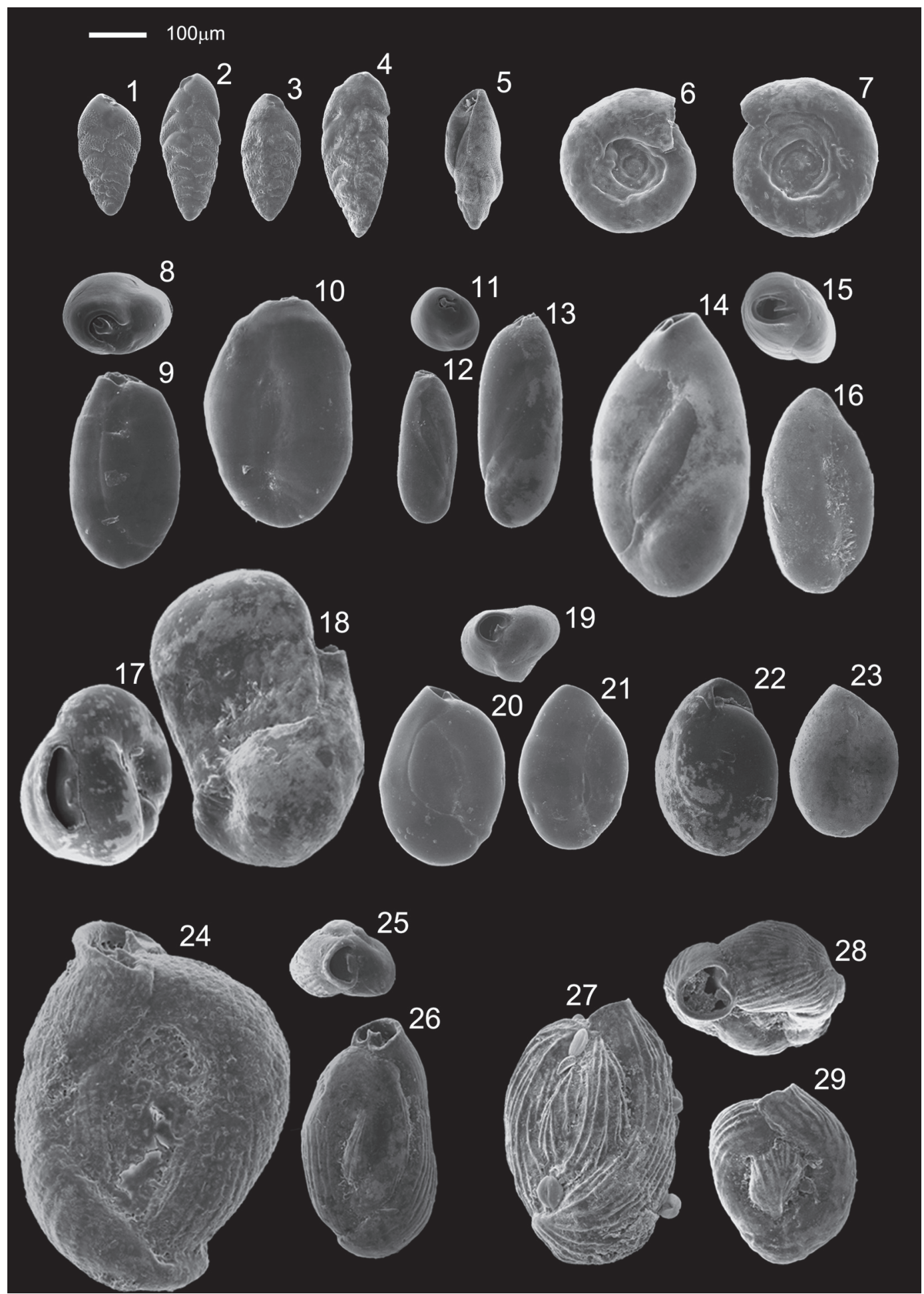

FIGURE 4. Scanning electron micrographs of the foraminifera specimens. Scale bar equals $100 \mu \mathrm{m}$. 1-4- different sized specimens of Bolivina ordinaria Phleger and Parker, 1952, new name; 5- Buliminella elegantissima (d'Orbigny, 1839b); 6-7- Cornuspira involvens (Reuss 1850); 8-10- Miliolid sp1; 8- apertural view; 9- front view; 10- back view; 1113- Miliolid sp2; 11- apertural view; 12- front view; 13- back view; 14-16- Miliolid sp3; 14- front view; 15- apertural view; 16- back view; 17-18- Miliolid sp4; 17- apertural view; 18- front view; 19-21- Miliolid sp5; 19- apertural view; 20 front view; 21- back view; 22-23- Miliolid sp6; 22- front and apertural view; 23- back view; 24-26- Miliolid sp7; 24- front view; 25- apertural view; 26- front and apertural view; 27-29- Miliolid sp8; 27- front view; 28- apertural view; 29- front view of a smaller specimen. 


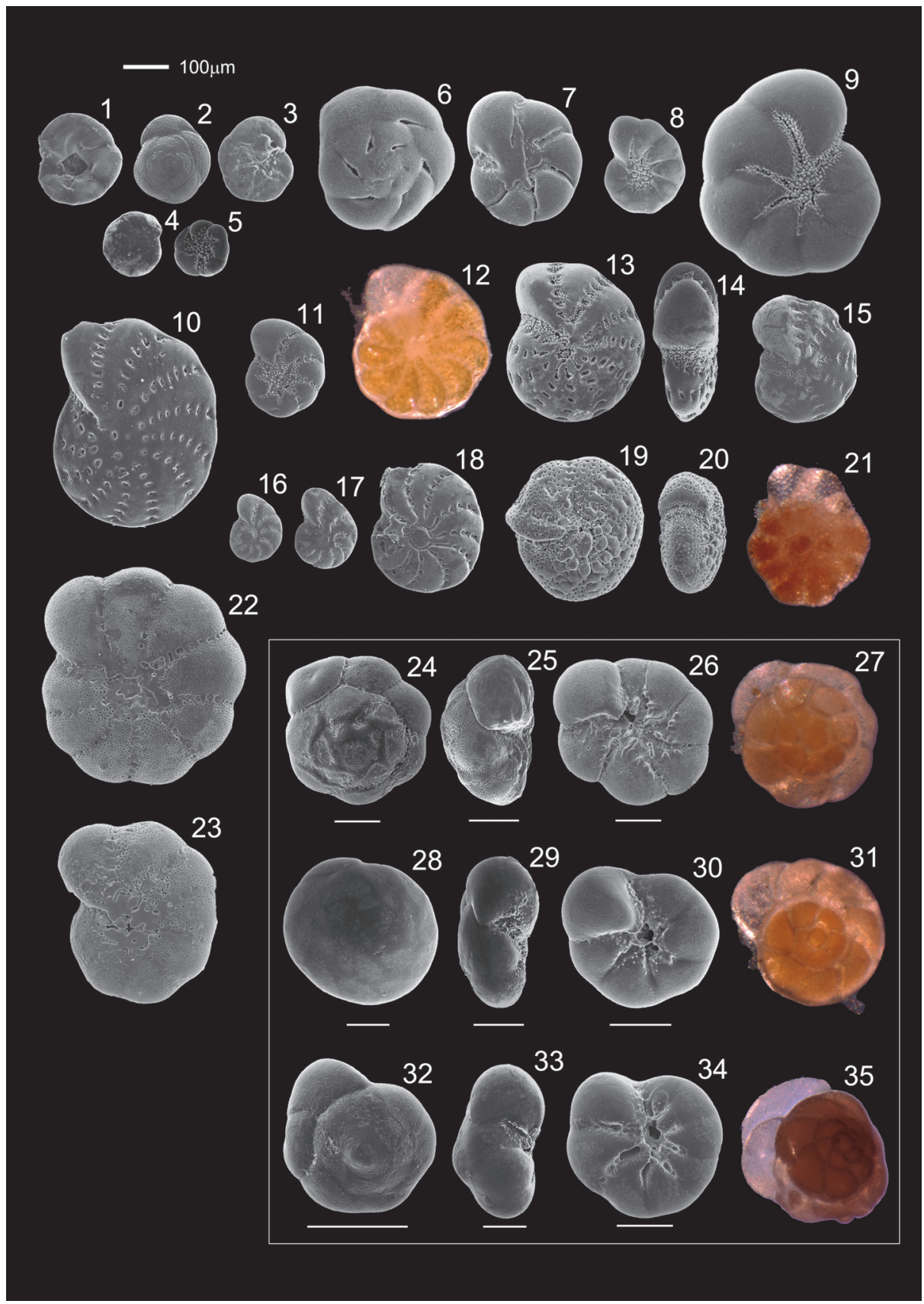

FIGURE 5. Scanning electron and light microscope micrographs of the foraminifera specimens. Scale bar equals 100 $\mu \mathrm{m}$. 1- Lamarckina haliotidea (Heron-Allen and Earland, 1911) ventral view; 2-3- Asterigerinata mamilla (Williamson, 1858); 2- dorsal view; 3- ventral view; 4-5- Discorbis sp.; 4- dorsal view; 5- ventral view; 6-7- Helenina anderseni (Warren, 1957); 6- dorsal view; 7- ventral view; 8- Haynesina depressula (Walker and Jacob, 1798) side view; 9- Haynesina germanica (Ehrenberg, 1840) side view; 10- Elphidium advenum (Cushman, 1922) side view; 11- Elphidium excavatum (Terquem, 1875) side view; 12-15- Elphidium wiliamsoni Haynes, 1973; 12- side view in light microscope image; 13- side view in scanning electron image; 14- profile view in scanning electron image; 15- side view of a smaller specimen in scanning electron image; 16-18- side view of different size Elphidium gerthi Van Voorthuysen, 1957; 19-21- Elphidium oceanensis (d'Orbigny, 1826); 19- side view in scanning electron image; 20- profile view in scanning electron image; 21- side view in light microscope image; 22- Elphidium poeyanum (d'Orbigny, 1826) side view; 24-27- Ammonia sp1; 24- dorsal view; 25- profile view; 26- ventral view; 27- dorsal view in light microscope image; 28-31- Ammonia sp2 (Ammonia aberdoveyensis Haynes, 1973); 28- dorsal view; 29- profile view; 30- ventral view; 31- dorsal view in light microscope image; 32-35- Ammonia sp3 (Ammonia aberdoveyensis Haynes, 1973); 32dorsal view; 33- profile view; 34- ventral view; 35- dorsal view in light microscope image. 
(1987), Jones (1994) and the Ellis and Messina (1942-2012) online catalogue. The foraminiferal collection gathered during the study of Guadiana River paleoenvironments (Boski et al., 2002, 2008) was the main reference for taxonomic identification.

Most of the foraminifera were classified according to the generic classification proposed by Loeblich and Tappan (1987). For the higher levels of taxonomy, other than genus and species, the WoRMS classification was followed (Hayward et al., 2014), including the recent modifications proposed by Cavalier-Smith (2010).

In collaboration with the project foram BARCODING, a molecular database of foraminifera based at Geneva University and coordinated by Pawlowski and Holzmann (2014), several species were analysed at genetic level. To accomplish this, two extra field campaigns were made with the aim of collecting live specimens, the first in November 2010 and the second in March 2011. During both campaigns, the most fruitful sites identified during the previous sampling campaigns in terms of foraminiferal densities were revisited and resampled. Samples of the top centimeter of sediment were collected by hand with a scraper. In the laboratory, two subsamples were taken and washed. One was stained with Rose Bengal to evaluate the quantity and quality of live specimens; the other was left to settle for 2 hours in sea water. Living foraminifera (indicated by bright, colorful protoplasms, movement and sediment aggregation) were isolated using a stereomicroscope, and selected specimens were put into tubes, each containing $50 \mu \mathrm{l}$ guanidine extraction buffer. Up to 10 live specimens of each species were separated and sent to the Geneva laboratory for genetic analysis and stereomicroscope photography.

The DNA extraction methodology was adapted from the general procedure in Pawlowski and Holzmann (2014), detailed in Pawlowski (2000). The analyzed barcoding region is situated at the 3' end of the SSU rRNA gene and is amplified using the primer pairs s14F3 (acgcamgtgtgaaacttg)-sB (tgatccttctgcaggttcacctac). It is usually necessary to perform a nested PCR, replacing primer 14F3 with primer 14F1 (aagggcaccacaagaacgc). The barcoding region spans six foraminifera-specific hypervariable expansion segments, 37f, 41f, 43f, 45e, $47 \mathrm{f}$ and $49 \mathrm{e}$, which were shown to be sufficiently variable to differentiate between closely related species. The length of the barcoding region varies between 1000-1200 nucleotides depending on the species. Most amplifica- tions are done on single-cell DNA extractions. Because of intra-individual polymorphism, the amplification products are cloned and two to three clones are sequenced. After sequencing the results were aligned to confirm the presence of the species.

\section{Data Analysis}

Statistical analyses were performed based on the relative abundance of the living foraminiferal species with representations higher than 10\% (Boltovskoy and Totah, 1985) in at least one sample.

Redundancy Analysis (RDA) (a constrained form of the linear ordination method of PCA) was chosen to analyse the relationships between the dominant species and elevation and distance-tosea, which were the two most important environmental variables in living foraminiferal distribution in Guadiana River Estuary (Camacho et al., 2015). In the present work, RDA was performed with a focus on inter-species correlations, where abundances of individual dominant species are transformed to a comparable scale. The relationship between species and environmental variables is represented by an attribute plot, where arrows represent the environmental variables, and species are represented by symbols of variable size according to its abundance in the sample scores fitted by the model (Leps and Smilauer, 2003).

\section{RESULTS AND DISCUSSION}

\section{Classification and Genetic Analysis}

There is a tendency among foraminiferal taxonomists to raise varieties and subspecies to species rank and to distinguish new species on the basis of subtle morphologic differences. Likewise, differences between genera are becoming smaller. Collectively these trends reduce the chances of consistent identification because the system depends on the judgment of each observer, rather than on unambiguously defined criteria (Murray, 2007). In order to avoid contributing to this general trend towards taxonomic entropy, several taxa were left in open nomenclature or in incertae sedis. This was the case of the miliolids, which, in the absence of type material and similarities with other miliolids in the same geographical area (e.g., Colom, 1974; Villanueva et al., 1999), were assigned code names.

Analysis of partial rRNA genes only yielded results for a limited number of species, among which only two were sucessfuly identified and reg- 
istered in the European Nucleotide Archive (http:// www.ebi.ac.uk/ena/data/view/LN551930-

LN551935): Ammonia aberdoveyensis Haynes (1973) (accession numbers: LN551930LN551933) and Elphidium williamsoni Haynes (1973) (accession numbers: LN551934LN551935).

The Ammonia genus includes species that are among the most common benthic foraminifera in the shallow waters of marginal marine environments globally (Langer and Leppig, 2000). With 35 taxa so far described, the genus Ammonia exhibits a significant range of morphological variants, making species-level identification particularly difficult morphologically (Holzmann et al., 1998; Langer and Leppig, 2000; Hayward et al., 2004). A variety of specific epithets for Ammonia morphotypes are in current use along the Guadiana Estuary and adjacent shelf (see Ruiz et al., 1996, 2005; Boski et al., 2002, 2008; Mendes et al., 2004, 2012; Delgado et al., 2012). Aiming to better understand Ammonia genetic affinities and clarify some of these taxonomic problems, we subjected three morphological variants to genetic analysis. Of these, only two produced successful results (Ammonia sp2 and sp3), being both aligned with Ammonia T2 (Hayward et al., 2004), thus corresponding to the species Ammonia aberdoveyensis Haynes (1973). Further field collections were performed, but genetic analysis of Ammonia sp1 proved fruitless. While some morphological dissimilarity was observed between the three variants (Figure 5.24-35), these characteristics were not significantly correlated with specific environmental conditions. Thus, further analysis is required to determine whether Ammonia sp1 is a different taxon or belongs to the species $A$. aberdoveyensis, with morphological differences resulting only from intergradational morphology.

\section{Seasonal Species Distribution}

Seasonal species distribution within the estuary was studied in detail in Camacho et al. (2015). Here we synthesize the main findings in that work with new observations on species distribution patterns and major environmental forcing parameters. Of the 54 living foraminifera taxa identified in the Guadiana Estuary, only 15 presented abundances $\geq 10 \%$. Jadammina macrescens (Brady, 1870), Trochammina inflata (Montagu, 1808), Miliammina fusca (Brady, 1870), Ammonia spp. and Haynesina germanica (Ehrenberg, 1840) were dominant in both seasons. Bolivina ordinaria Phleger and Parker (1952), Miliolid sp3 and the miliolids group (dominant) and Asterigerinata mamilla (Williamson, 1858), Discorinopsis aguayoi (Bermúdez, 1935) and Miliammina obliqua Heron-Allen and Earland (1930) (common) were only found in winter. Polysaccammina hyperhalina, Polysaccammina ipohalina and Elphidium oceanensis (dominant) and Siphotrochammina sp. were only found in summer. Seasonal distribution profiles for each dominant species, according to the environmental variables of elevation and distance-to-sea, are shown in Figure 6.

Winter distribution of the main species. The distribution of common and dominant species during winter is represented in Figure 7. According to the division of the marsh into different elevation zones, it is clear that the upper marsh was almost exclusively colonized by the agglutinated species $J$. macrescens. In two of these samples, LEZ2 and VRSA2, there was a marked abundance of porcelaneous species, especially in LEZ2, where this group represents $82.3 \%$ of the total individuals (Appendix, Tables 2 and 3).

The lower marsh zone had more diverse foraminiferal composition than in the upper marsh. At the most confined sites (E1, located in the margin of a small tidal pond, and LG2 and LG3, located at the margin of a shallow, small lagoon), J. macrescens was dominant alongside $T$. inflata. Ammonia spp. and $H$. germanica had their highest representation in the samples collected in the lower marsh and mud zones of the lower estuary (Figure 7). Ammonia spp. exhibited a more euryhaline behavior than $H$. germanica, being abundant in the upper reach sample (FO), as well as in the lagoonal environment (LG3), which occupies the most downstream position. The agglutinated species $M$. fusca had its optimum spanning from the upper reaches of the lower estuary to the middle estuary, in samples from lower marsh-mud zone. Bolivina ordinaria is common in the lower marsh but had its optimum in mud zone areas, occurring together with Ammonia spp. and $H$. germanica. Polysaccammina hyperhalina Medioli et al. (1983) (Petrucci et al., 1983) occurred mainly in the mud zone.

It is worth pointing out that the porcelaneous forms, represented here by the miliolids group and Miliolid sp3, only occurred in environments subject to some degree of confinement, such as the samples located in the upper marsh and the small lagoon site (LG).

Summer distribution of the main species. The distribution of the common and dominant taxa during summer is represented in Figure 8. It is pos- 

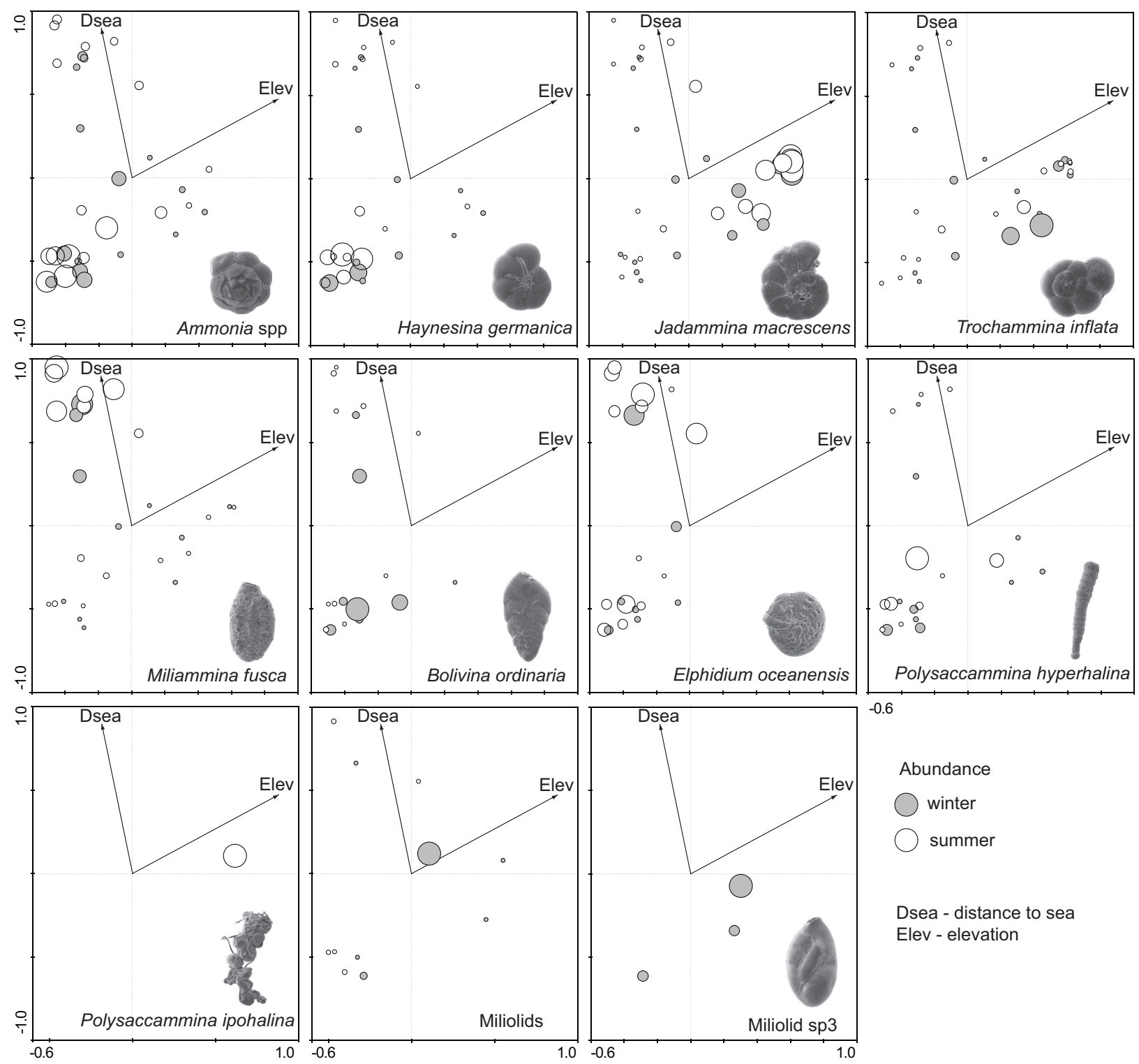

Abundance

winter

summer

Dsea - distance to sea

Elev - elevation

FIGURE 6. RDA attribute plot representing the distribution and abundance of the dominant species in Guadiana Estuary according to elevation and distance-to-sea variables.

sible to see that the upper marsh was almost exclusively colonized by the agglutinated species J. macrescens, similarly to the situation during winter. The exceptions were samples SCM, LEZ2 and VRSA2, where other species had significant abundances. At SCM, the site farthest inland from the estuary channel, J. macrescens shares dominance with P. ipohalina Scott (1976b), the latter representing more than $20 \%$ of the individuals and exclusive to that sample, suggesting specific environmental conditions. At LEZ2 and VRSA2, both samples located in the lowermost position within the upper marsh (1.06 and 1.03 meters above $\mathrm{MSL}$ ), J. macrescens lost prominence to other spe- cies, such as $P$. hyperhalina, M. fusca, Ammonia spp. and E. oceanensis, suggesting that the elevation thresholds for the latter species were above the $1 \mathrm{~m}$ level.

In the lower marsh the assemblages are more diversified, especially in samples located on the channel margin, where J. macrescens loses dominance. At more confined locations (FB2, E1, LG2 and LG3) J. macrescens is still prominent but shares dominance with $T$. inflata, Ammonia spp. and $M$. fusca. When considering foraminifera distribution in the lower marsh, the dominance of $M$. fusca stands out. This species had its optimum in the middle elevations $(0-1 \mathrm{~m})$ of the upper 


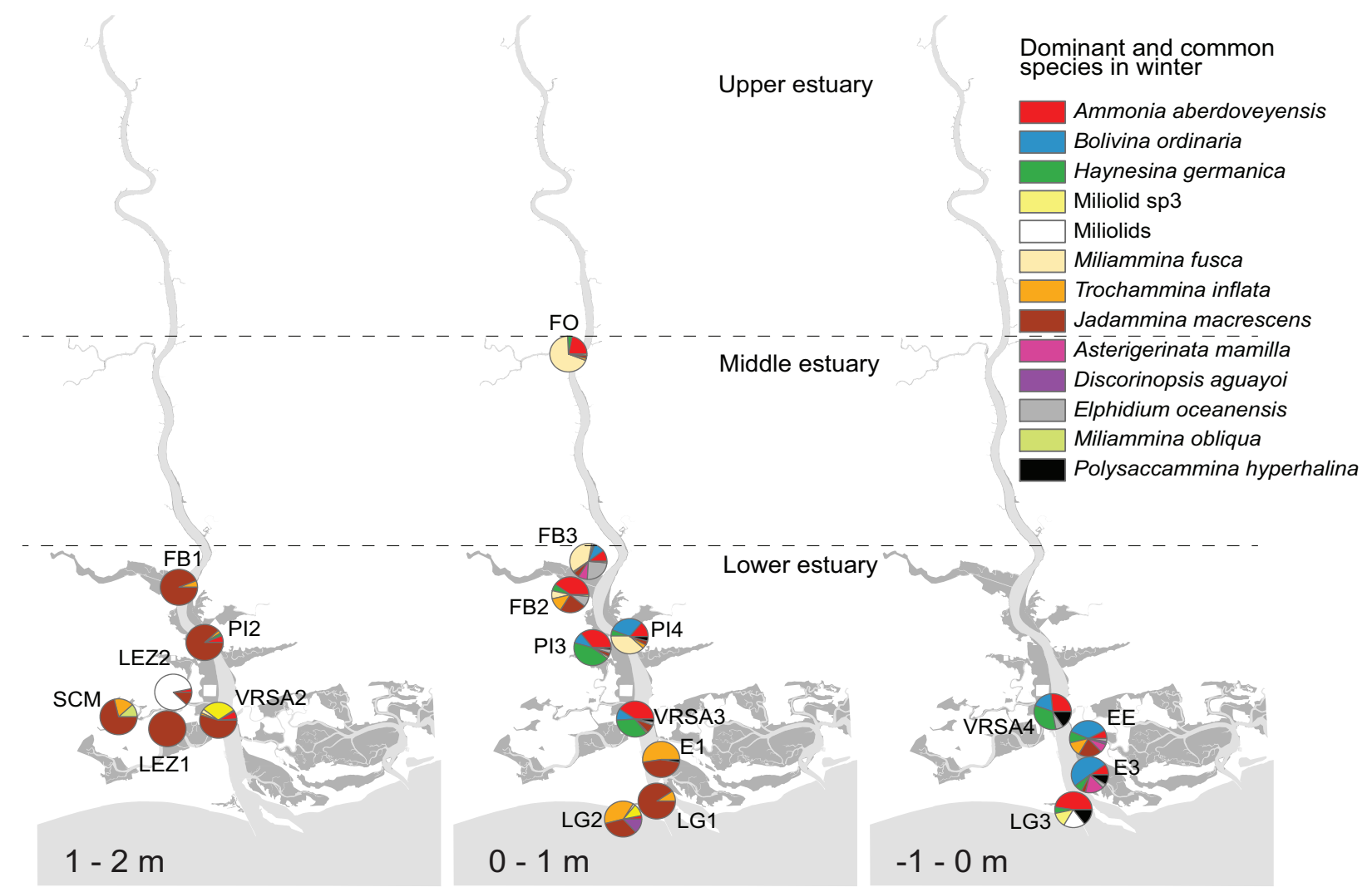

FIGURE 7. Distribution patterns of the common to dominant species in the samples collected in winter along a distance-to-sea and elevation gradients (in relation to MSL).

reaches of the lower estuary to middle estuary and is associated with Ammonia spp. and E. oceanensis. In the lower marsh, it is important to point out that the species Siphotrochammina sp. was only found alive at the Aouro site, located approximately $16 \mathrm{~km}$ upstream from the inlet, showing significant abundance. Ammonia spp. had its optimum in the samples collected in the mud zone, where it was dominant. Of all studied species, it was the most euryhaline, being recorded at considerable percentages along the distance-to-sea gradient and in the most confined environments of the lower marsh, as well as in some samples of the upper marsh. It was closely associated with $H$. german$i c a$, especially in the mud zone, and with $E$. oceanensis in both lower marsh and mud zone. Polysaccammina hyperhalina, which was restricted to the mud zone in winter, had a patchy distribution in summer, more dependent on site location than on the elevation of the sample.

\section{Species Ecology and Biogeography}

Almost all the common and dominant species described in the present work are cosmopolitan, occurring in other estuaries all over the world (Sen Gupta, 1999) and several of them were previously recorded by Ruiz et al. $(1996,2005)$ and González et al. (2000) in Guadiana Estuary. A new finding is that both $M$. fusca and $P$. hyperhalina, which are presently very abundant and constant along the estuary, were not reported by previous authors who studied the same area. Moreover, $P$. hyperhalina, $P$. ipohalina, $M$. obliqua and $D$. aguayoi are reported for the first time in the Guadiana Estuary, and, to our knowledge, in Portugal.

Jadammina macrescens is one of the species with the greatest scientific consensus in terms of life position and ecological indicator value. The first applications of marsh foraminifera in reconstruction of episodes of mean sea-level change were based in monospecific assemblages of $J$. macrescens (syn. Trochammina macrescens) collected near the continental limit (high marsh) in Nova Scotia marshes (Scott and Medioli, 1978, 1980). Being the most tolerant species to subaerial exposure, its relative abundance is very useful in sea-level change studies because it reflects the elevation of the depositional environment in relation to the high- 


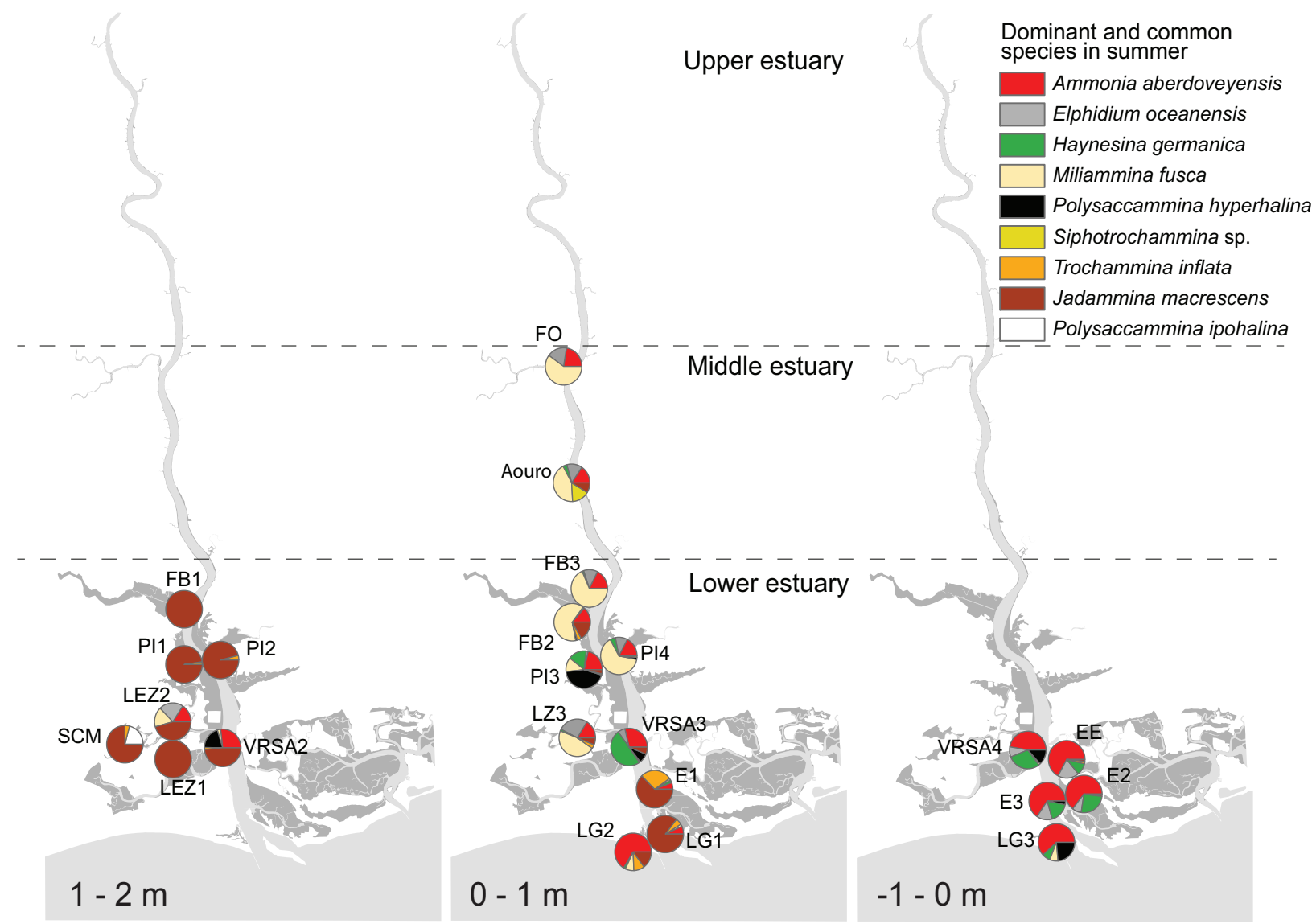

FIGURE 8. Distribution patterns of the common to dominant species in the samples collected in summer along a distance-to-sea and elevation gradients (in relation to MSL).

est high-water level, where it may represent $100 \%$ of foraminiferal assemblages, decreasing towards the low marsh, where it is almost absent (Scott and Medioli, 1978, 1980). Therefore, its relative abundance is inversely related to tide-flood frequency and other species' relative abundance (diversity) and has thus been used as an indicator of flood frequency (Thomas and Varekamp, 1991; Varekamp et al., 1992). In the present work, J. macrescens is the most widespread species, occurring in almost all samples from winter $(94.7 \%)$ and summer $(82.6 \%)$ (Figure 6$)$. In the most elevated positions, the assemblages are almost exclusively (and in some cases, exclusively) composed of $J$. macrescens, exhibiting uncommonly high densities in some places (e.g., 68266 individuals/ $20 \mathrm{cc}$, in sample LG1 during winter) (Figures 7, 8). In a time-series study performed in the Tees Estuary, UK, Horton and Murray (2007) monitored J. macrescens standing crops fortnightly over 12 months and recorded peaks in abundance during the year. The maximum standing crop was $864 / 10$ cc in October, being far less than the 34133 individ- uals/10 cc in Guadiana sample LG1. Furthermore, Horton and Murray (2007) observed a progressive decline of this species from May/June, where it represents more than $80 \%$, to March ( $5^{\text {th }}$ day), when it temporarily disappeared. Our winter sampling, with high densities of $J$. macrescens, coincided exactly with the absence period verified by Horton and Murray (2007). These samples have a strong component of juveniles (generally more than $50 \%$ of the total, pers. obs.), extremely small and fully stained, which were 'hidden' in small mucous sediment aggregates, and were only visible when these were disaggregated with a probe. The counting of these hidden specimens may explain the large differences between the densities found in this work and others in which J. macrescens was also dominant. In summer, the juvenile component is always present and, although generally less than $50 \%$, there are some samples in which it is higher. These observations lead us to conclude that, in the Guadiana, this species has the capacity of reproducing in both seasons, although winter seems more favorable. While juve- 
niles are always present in samples containing adult $J$. macrescens, there are considerable differences between the adult/juvenile proportions from sample to sample, especially in summer. This seems to suggest that, within the same geographical area, the species does not reproduce at the same time, or at least at the same scale, which points to the influence of other abiotic and/or biotic factors acting locally and in parallel with seasonality in triggering reproduction.

Trochammina inflata is closely related to $\mathrm{J}$. macrescens, occurring together in almost all the samples and being more abundant during winter, although it has higher abundances in the lower marsh (0.2 to $0.8 \mathrm{~m}$ above MSL at samples E1, LG2 and FB2) where J. macrescens abundance starts to decrease and species diversity starts to increase (Figures 7,8 ). This relationship was reported previously for the Guadiana (González et al., 2000; Ruiz et al., 2005), and in other areas (some of the Nova Scotia marshes-Scott and Medioli, 1980; Fraser River Delta-Patterson, 1990). In other estuarine systems all over the Iberian Peninsula (Morbihan, Basque, Minho-Lima and SadoLeorri et al., 2010), both J. macrescens and $T$. inflata are dominant components at the most elevated zones, but species association/succession is not exactly the same as that found in the Guadiana, probably due to local environmental differences. No other species is intrinsically related to $J$. macrescens and T. inflata, but several species with ephemeral occurrences seem to share similar habitat preferences. In the lower estuary in winter, the Miliolids group and Miliolid sp3 have peaky occurrences, each in a distinct sample of the upper marsh: LEZ2 (82.3\%) and VRSA2 (28.8\%), respectively (Figure 7). In summer it is worth noting the ephemeral occurrence of $P$. ipohalina at SCM, where it is subdominant to $\mathrm{J}$. macrescens (20.8 and $75 \%$, respectively). Polysaccammina ipohalina is a high marsh species (or upper mangrove, Barbosa et al., 2005), usually representing a minor component in estuarine systems (Scott, 1976b; Scott and Medioli, 1980; Scott et al., 1990). It was firstly described by Scott (1976b) in San Dieguito Marsh, California, associated with a few other species, especially $\mathrm{J}$. macrescens polystoma and $T$. inflata. Although the latter species are common to almost every marsh, from brackish to hypersaline, when the association includes $P$. ipohalina it indicates a brackish marsh environment (Scott, 1976b). In the present study, salinity was measured in both seasons at site SCM, a sample located at the margin of a salt-works pond (Cama- cho et al., 2014). Here, salinity is relatively high in both seasons (winter - 14.3 and summer - 26.1) when compared with those measured by Scott (1976b) (2-10\%). A common characteristic of SCM and San Dieguito marsh is the lack of tidal activity, which raises the possibility that this species is conditioned primarily by confinement and temperature.

In winter, at the SCM site, $P$. ipohalina is replaced by $T$. inflata and $M$. obliqua. Hayward et al. (1999b) have characterized $M$. obliqua as largely restricted to Southern Hemisphere shores (New Zealand marsh environments) where it occurs with J. macrescens and T. inflata. Based on the present experience, we believe that the strong morphological similarities between $M$. obliqua and $M$. fusca may be a hindrance to accurate identification, not only in Portuguese estuarine systems, but also worldwide, since the former taxon is rarely mentioned in the literature. In the Guadiana, $M$. obliqua exhibits higher incidence in winter in the lower marsh of the upper estuary and in two samples of the upper marsh with a more confined position.

Discorinopsis aguayoi, like $M$. obliqua, is a species of narrow distribution, occurring with $J$. macrescens and $T$. inflata in significant abundances $(11.9 \%)$ during winter. In the living assemblage, its occurrence seems limited to the lower marsh zone, at the sheltered marine lagoon in the inlet (LG). Discorinopsis aguayoi is regarded as an indicator of landlocked marine/brackish ponds, mangrove marshes (Javaux and Scott, 2003) and high marsh in warm temperate environments (Scott, 1976a; Scott et al., 1990). Despite being very well documented by the latter authors, $D$. aguayoi was never mentioned as an epiphytic species. In the Guadiana it is found strongly attached to vegetal structures, each specimen having to be carefully detached using a needle probe.

The Ammonia genus includes species that are among the most common benthic foraminifera in shallow waters of marginal marine environments (Langer and Leppig, 2000; Debenay and Guilou, 2002). In the Guadiana Estuary, Ammonia spp. ( $A$. aberdoveyensis and Ammonia sp1) is the most ubiquitous calcareous taxon, being absent only from the most elevated samples $(>1.3 \mathrm{~m}$ in relation to MSL - PI1, FB1, SCM, LEZ1). Its optimum occurrence is in the mud zone to lower marsh (-1 $1 \mathrm{~m}$ ) of the lower and middle estuary (Figures 7,8 ). Its peak of occurrence is observed in summer, especially in the mud zone where it is always the dominant taxon (Figure 8). It is noteworthy that, in 
summer, Ammonia spp. are able to migrate farther up the marsh, occupying higher elevation stands, probably due to decreased inter-species competition. Ammonia spp. are dominant in two of the main assemblages found for Guadiana: the lower marsh $(0-1 \mathrm{~m})$ upper reaches assemblage, where they are subdominant to $M$. fusca, and the mud zone $(-1-0 \mathrm{~m})$ of the lower estuary, where they are co-dominant with $B$. ordinaria in winter.

Haynesina germanica is closely associated with Ammonia spp., occurring as subsidiary species in almost all samples where Ammonia spp. are present (Figures 7,8$)$. The dominance of these two hyaline forms (Ammonia tepida (Cushman, 1926) or Ammoni beccarii (Linné, 1758) instead of our Ammonia spp.) has been documented for the estuarine systems of the whole of Europe (see Redois and Debenay, 1996). Both species are resistant to strong physico-chemical changes such as anoxia crises (common in the Mediterranean Sea and stratified lagoons), which require rapid recolonization (Debenay et al., 1998c; Frontalini and Coccioni, 2011). In the temperate paralic environments of the Atlantic coast of France, $H$. germanica is the most euryhaline and opportunistic hyaline species, marking the transition between agglutinated forms from upper paralic environments (where it is dominant) to calcareous forms from environments of higher marine influence, being progressively replaced by $A$. tepida (Redois and Debenay, 1996; Debenay et al., 2000; Debenay and Guilou, 2002). Horton and Murray (2007) found H. germanica among the dominant calcareous species from the tidal flats to middle marsh environments, and Ammonia spp. as sub-dominant, ephemeral-occurrence taxa. Martins et al. $(2010,2013)$ found $H$. germanica to be the most abundant species, followed by A. tepida, in the Ria de Aveiro, NW Portugal. In the Guadiana Estuary, H. germanica is not as prominent as Ammonia spp. but is very constant and is even dominant in a few samples of the lower marsh-mud zone. However, our data do not reveal the zonation pattern observed by Redois and Debenay (1996), Debenay et al. (2000) and Debenay and Guilou (2002). Instead, it seems that Ammonia spp. is the best-established calcareous taxon in the estuary, and, together with E. oceanensis, the most able to migrate farther up the marsh and upstream. A similar distribution was found in Venice Lagoon (Serandrei-Barbero et al., 1999) and at Acheloos and Evinos Estuaries (Greece) (Scott et al., 1979), where in both areas the lower stands are dominated by Ammonia with significant components of Elphidium and Hayne- sina. These and the Guadiana Estuary distributions seem to indicate that Ammonia is the dominant component in the low stands of the estuarine wetlands in southern Europe's warmer Mediterranean environments; whilst in north Europe's colder oceanic environments, $H$. germanica has higher prominence as a lower stands species.

According to Hayward et al. (1997), E. gunteri (here $E$. oceanensis) has a middle to low latitude distribution, with preference for warmer waters. It is also associated with brackish waters (Fatela and Silva, 1990; Debenay et al., 2003). In the Guadiana, E. oceanensis has its optimum during summer, being a dominant species in the lower marshmud zones (-0.7 to $1.1 \mathrm{~m}$ in relation to $\mathrm{MSL}$ ) (Figure 6). In terms of distribution range, it is almost as eurytopic as Ammonia spp., occupying the entire study range of elevation and latitude.

Bolivina ordinaria has a controversial taxonomic history in the literature, as various names have been used by different authors to describe similar specimens worldwide (see Mendes, 2010, for review). The direct comparison of our specimens with the specimens of Mendes (2010) led us to conclude that both belong to the same species and thus Mendes' (2010) identification criteria were adopted. Bolivina ordinaria distribution within the Guadiana Estuary was surprising, as it is primarily described as an abundant species at great depths on the Portuguese continental shelf (Mendes et al., 2004; Martins et al., 2006, 2007; Mendes, 2010). Mendes (2010) considered $B$. ordinaria as a ubiquitous, very abundant species, highly adaptable and tolerant to a wide range of different factors or combination of factors, living at two different continental-shelf depth ranges (25-100 $\mathrm{m}$ in the southeast and $20-60 \mathrm{~m}$ in the northwest Gulf of Cadiz), and strongly associated with the direct influence of river discharges. She also found a peak abundance of $B$. ordinaria at $50 \mathrm{~m}$ depth and related it to a high rate of productivity at that depth. Mendes et al. (2004) previously described B. ordinaria as an important component of the shelf deep-water assemblage, relating it to low hydrodynamic levels, low-oxygen fine-grained sediments and to coldwater incursion derived from upwelling events. This species was also found in significant numbers in benthic foraminiferal assemblages from areas of greater marine influence offshore from the Ria de Aveiro, associated with fine-grained sediments enriched in TOC (Martins et al., 2014). Debenay and Redois (1997a,1997b), in a survey regarding foraminiferal distribution on the continental shelf in North Senegal, related the presence of Bolivina 
spp. to the fertility of upwelling waters and Senegal River discharges. Likewise, Lévy et al. (1993) related two species of Bolivina with upwelling events along the southern coast of Portugal. In the Guadiana Estuary, B. ordinaria occurs as a dominant species in winter. In summer it is less frequent and less abundant (Figure 7). Depth and low hydrodynamics are not regarded as conditioning factors, as the species occurs in environments above MSL $(<0.61 \mathrm{~m})$ and during winter, when the estuary experiences higher hydrodynamics. Passive upriver transportation by tides could explain its distribution, but then it would be expected to occur mainly in summer when the residence times are higher due to low river flows (Oliveira et al., 2006). From the overall environmental drivers discussed here, productivity and low temperatures seem to be the common factors in controlling the occurrence of $B$. ordinaria in both the estuary and deep shelf environments. In the Guadiana Estuary, during the rainy seasons (winter and spring), river inputs of freshwater are higher, enhancing the bioavailability of nutrients, especially $\mathrm{Si}$, promoting the bloom of diatoms, which are the preferred food source for healthy foodwebs (Dias et al., 2001; Rocha et al., 2002). The low temperatures (indirectly) and productivity (directly) could be triggering $B$. ordinaria reproduction and proliferation inside the estuary.

Miliammina fusca is a very common species in worldwide paralic environments, dominating the continental end-member, and associated with direct freshwater influence (see Debenay and Guilou, 2002 for review). It is considered as an indicator species of the low-mid marsh zone (Varekamp et al., 1992) and the most ubiquitous agglutinated shallow-water species (Murray and Alve, 1999). In the Guadiana estuary, $M$. fusca is the most ubiquitous agglutinated shallow-water species, dominating assemblages either in the upper reaches of the lower estuary and upstream, at middle elevation zones $(0-1 \mathrm{~m})$ (Figure 6). Along with the indigenous calcareous species (Ammonia spp. and Elphium oceanensis), M. fusca is most abundant during summer, when it often represents more than $50 \%$ of the total assemblage (Figure 8). The species also seems able to migrate farther up the marsh in summer (e.g., LEZ and FB transects), reaching $16.3 \%$ at $1.06 \mathrm{~m}$ above MSL (LEZ2 sample).

Polysaccammina hyperhalina is a common and nearly constant agglutinated species in the Guadiana Estuary. In winter, its distribution seems to be restricted to the mud zones, whilst in summer it reaches higher abundances in the lower marsh as well (Figure 6). Polysaccammina hyperhalina is a species of hypersaline environments and was first reported and described from Venice Lagoon (Petrucci et al., 1983). In the Guadiana Estuary, the species has its optimum at the lower elevations of the lower estuary (Figures 7, 8), where marine processes are more pronounced. In northwest Portugal's paralic systems, $P$. hyperhalina was not recorded as a prominent species by Martins et al. (2010) in the Canals of Ria de Aveiro, nor found by Moreno et al. (2005) and Fatela et al. (2009) in the Minho and Coura estuaries. The presence/ absence of this species may be related not only to salinity but also to temperature, as $P$. hyperhalina seems to prefer warmer climates, as noted by Petrucci et al. (1983) when they compared faunas from Venice Lagoon, Greece and Southern California.

Debenay et al. (2000) and Debenay and Guilou (2002) reviewed ca. 1500 samples collected worldwide by several authors in various types of transitional environments and synthesized the main foraminiferal distribution trends for each geographical and climatic zone. Despite several similarities between the general distribution model they proposed for temperate North Atlantic transitional environments and those studied by Horton and Murray (2007) (UK), Moreno et al. (2005), Fatela et al. (2009) and Martins et al. (2010) (north of Portugal), the benthic foraminifera distribution trends found in Guadiana Estuary present greater similarities with the distribution trends observed in Mediterranean transitional environments (Scott et al., 1979; Petrucci et al., 1983; Serandrei-Barbero et al., 1999; Debenay et al., 2000). In Mediterranean transitional environments, $J$. macrescens and $T$. inflata are prominent species in the upper marsh zone, occasionally associated with $D$. aguayoi. The middle marsh is characterized by the presence of M. fusca, occasionally associated with Ammonia, $P$. hyperhalina, T. inflata and Quinqueloculina seminula. Mudflats and low marshes are characterized by the presence of Ammonia, sometimes alongside Haynesina germanica.

The high diversities observed in Guadiana (Camacho et al., 2015) and the dominance of thermophilous taxa (Ammonia spp., D. aguayoi, E. oceanensis and $P$. hyperhalina) reflect the estuary's geographical position, which is subject to both Mediterranean and Atlantic influences. 


\section{SYSTEMATIC PALAEONTOLOGY}

Order ASTRORHIZIDA Lankester, 1885

Family POLYSACCAMMINIDAE Loeblich and

Tappan, 1984

Genus POLYSACCAMMINA Scott, 1976b

Polysaccammina ipohalina Scott, 1976b

Figure 2.1-3

1976b Polysaccammina ipohalina Scott: p. 316, pl. 2, figs. 1-4, text fig. 4a-c.

1980 Polysaccammina ipohalina Scott; Scott and Medioli, p. 43, pl. 2, figs. 8-11.

1991 Polysaccammina ipohalina Scott; Scott, Suter and Kosters, p. 386, pl. 2, fig. 3.

2005 Polysaccammina ipohalina Scott; Barbosa, Scott, Seoane, and Turcq, p. 40, pl. 1, fig. 12.

Morphological description. Test free, finely arenaceous with pseudochitinous base; globular chambers, irregularly shaped, in uniserial arrangement but sometimes irregularly developed; with terminal aperture; test is flexible at sutures; earlier chambers appear to collapse; sutures distinct and depressed; arenaceous outer layer is not continuous between chambers.

Occurrence. Dominant species along with Jadammina macrescens and Trochammina inflata. Narrow occurrence, recorded only in one site in the Guadiana, in the vegetated margin of a saltworks pond which feeds salt-pans reservoirs, during summer, at $1.96 \mathrm{~m}$ above MSL.

Remarks. Its amorphous aspect and similarities with organic matter debris could hinder identification of this taxon as it is rarely mentioned in other works concerning marsh and estuarine foraminiferal analysis. The species was originally described as non-attached; however, many of the species observed in Nova Scotia (Scott and Medioli, 1980) and in the present work were attached to organic debris (Figure 2.1-3).

Polysaccammina hyperhalina (Medioli, Scott and Petrucci, 1983 in Petrucci et al., 1983)

Figure 2.4-2.6

1870 Lituola findens Parker, 1870; Dawson, p. 8, fig. 1.

1913 Reophax findens (Parker, 1870); Rhumbler, p. 466, fig. CLXXV.

1983 Polysaccammina hyperhalina Medioli, Scott and Petrucci; Petrucci, Medioli, Scott, Pianetti and Cavazzini, p. 73, 74, pl. $1,2$.
1996 Reophax moniliformis Siddall, 1886; Redois and Debenay, p. 258, pl. 1, fig. 3.

2005 Polysaccammina hyperhalina Medioli, Scott and Petrucci; Barbosa, Scott, Seoane and Turcq, p. 40, pl. 1, figs. 10, 11.

Morphological description. Test coarsely to fine agglutinated, usually uniserial but often irregular and sometimes branching (Figure 2.5); chambers of irregular shape, either regularly increasing in size or remaining of the same size throughout; test flexible due to an inner pseudochitinous lining which can be observed at broken chamber connections; aperture terminal, round and ivaginated to form a inner, backward pointing funnel (Figure 2.6). Occurrence. Common and nearly constant agglutinated species; more common at the lower reaches of the estuary; in winter, its distribution seems restricted to the lower elevation zones, whilst in summer it reaches higher abundances at both the middle and lower elevations of the marshes.

Remarks. This species has a fragile test, easily broken during washing.

Order LITUOLIDA Lankester, 1885

Family AMMODISCIDAE Reuss, 1862

Genus AMMOVERTELLINA Suleymanov, 1959

Ammovertellina sp.

Figure 2.7-2.10

Morphological description. Proloculus followed by streptospirally wound tubular second chamber, later becoming planispiral; final stage uncoiling and with zig-zag or irregular growth; wall agglutinated, of angular quartz grains in insoluble cement; aperture at the open end of the tube.

Occurrence. Occurred only in the lower estuary, as a rare species.

Family REOPHACIDAE Cushman, 1927 Genus REOPHAX de Montfort, 1808 Reophax nana Rhumbler, 1913

Figure 2.11-2.14

1913 Reophax nana Rhumbler: p. 471, pl. 8, figs. 6-12.

1957 Reophax nana Rhumbler; Todd and Brönnimann, p. 22, pl. 1, fig. 17.

1980 Reophax nana Rhumbler; Scott and Medioli, p. 43, pl. 2, fig. 6.

2005 Reophax nana Rhumbler; Barbosa, Scott, Seoane and Turcq, p. 40, pl. 1, figs. 15-17.

Morphological description. Test agglutinated, uniserial, elongated; aperture simple on the top of the last chamber. 
Occurrence. Accessory species, occurring mainly at the lower stands of the marsh.

Genus LEPTOHALYSIS Loeblich and Tappan, 1984

Leptohalysis scottii (Chaster, 1892)

Figure 2.15-2.17

1892 Reophax scottii Chaster: p. 27, pl. 1, fig. 1.

1971 Reophax scottii Chaster; Murray, p. 17, pl. 1, figs. 6-9.

1995 Reophax scottii Chaster; Lévy, Mathieu, Poignant, Rosset-Moulinier, Ubaldo and Lebreiro, p. 18, pl. 1, fig. 15.

2011 Leptohalysis scottii (Chaster); Murray and Alve, p. 30, fig. 18.5 .

Morphological description. Test agglutinated uniserial and elongated; usually very thin and with somewhat angular chambers; an inner organic lining makes the test particularly flexible.

Occurrence. Species with rare occurrence along the estuary, at middle to low elevations of the marsh, revealing an exotic behavior.

Family LITUOLIDAE de Blainville, 1827

Genus AMMOBACULITES Cushman, 1910

Ammobaculites exiguus Cushman and Brönnimann, 1948b

Figure 2.18

1948b Ammobaculites exiguus Cushman and Brönnimann: p. 38, pl. 7, figs. 7, 8.

1953 Ammobaculites exiguus Cushman and Brönnimann; Parker, Phleger and Pierson, p. 5, pl. 1, fig. 16.

1986 Ammobaculites exiguus Cushman and Brönnimann; Brönnimann and Keij, pl. 3, fig. 7.

1995 Ammobaculites exiguus Cushman and Brönnimann; Scott, Hasegawa, Saito, Ito and Collins, p. 292, fig. 6.1.

2005 Ammobaculites exiguus Cushman and Brönnimann; Barbosa, Scott, Seoane and Turcq, p. 39, pl. 1, fig. 9.

Morphological description. Test agglutinated, elongate, initially planispirally coiled and latter with several uniserial chambers; aperture terminal and rounded.

Occurrence. Very rare, occurring only in one sample, near the Ayamonte Sewage Treatment Plant.

\section{Ammobaculites sp.}

Figure 2.19

Morphological description. Similar to $A$. exiguus although larger and usually with the uncoiled por- tion broken; chambers better differentiated than $A$. exiguus.

Occurrence. Occurred only at the lower estuary, as a rare species, between the middle and low marsh stands.

Genus AMMOTIUM Loeblich and Tappan, 1953

Ammotium salsum (Cushman and Brönnimann, 1948a)

Figure 2.20-2.22

1948a Ammobaculites salsus Cushman and Brönnimann: p. 16, pl. 3, figs. 7-9 (holotype figs. 7a, 7b).

1962 Ammotium salsum (Cushman and Brönnimann); Closs and Madeira, p. 15, Est. 3, fig. 8; p. 43, Est. 7, fig. 2.

1980 Ammotium salsum (Cushman and Brönnimann); Scott and Medioli, p. 35, pl. 1, figs. 11-13.

1991 Ammotium salsum (Cushman and Brönnimann); Scott, Suter and Kosters, p. 384, pl. 1, figs. 11-13.

1993 Ammotium morenoi (Acosta, 1940); Brönnimann and Whittaker, p. 121, fig. 54.

2003 Ammotium salsum (Cushman and Brönnimann); Duleba and Debenay, p. 77, pl. 1, fig. 10.

2011 Ammoscalaria pseudospiralis (Williamson, 1858); Murray and Alve, p. 28, fig. 16.12.

Morphological description. Test agglutinated, initially planispirally coiled and latter chambers tend to uncoil, forming a wide uniserial pattern with poorly defined, slightly slanting suture lines; aperture is terminal and oval (Figure 2.21).

Occurrence. Accessory species $(<10 \%)$ along the estuary, preferring the middle-low stands of the marsh; higher proliferation and densities during summer.

\section{Ammotium sp. \\ Figure 2.23}

Morphological description. Test finely agglutinated, initially planispirally coiled and latter chambers tend to uncoil, forming a wide uniserial pattern with slanting, well defined suture lines; much smaller than A. salsum.

Occurrence. Very rare species.

Family RZEHAKINIDAE Cushman, 1933

Genus MILIAMMINA Heron-Allen and Earland, 1930 
Miliammina fusca (Brady, 1870)

Figure 2.24-2.26

1870 Quinqueloculina fusca Brady: p. 286, pl. 11, figs. 2, 3.

1953 Miliammina fusca (Brady, 1870); Parker, Phleger and Pierson, p. 10, pl. 1, figs. 40, 41.

1980 Miliammina fusca (Brady, 1870); Scott and Medioli, p. 40, pl. 2, figs. 1-3.

1990 Miliammina fusca (Brady, 1870); Scott, Schnack, Ferrero, Espinosa and Barbosa, p. 731, pl. 1, fig. 4.

2003 Miliammina fusca (Brady, 1870); Javaux and Scott, p. 16, fig. 6.7.

2013 Miliammina fusca (Brady, 1870); GenBank, ID: 302103,

www.ncbi.nlm.nih.gov/Taxonomy/Browser/ wwwtax.cgi? $i d=302103 \&|v|=0$

Morphological description. Test agglutinated, elongated, ovate, of half coil in a quinqueloculine pattern; wall relatively thick, medium to coarse agglutinated; aperture at the end of the chamber, rounded to semilunate, depending on the degree of compression against the previous whorl and may be produced on a short neck.

Occurrence. One of the most ubiquitous agglutinated species in the Guadiana Estuary, dominating mid-low environments in the upper reaches of the estuary.

Miliammina obliqua Heron-Allen and Earland, 1930 Figure 2.27-2.28

1930 Miliammina obliqua Heron-Allen and Earland: p. 42, pl. 1, figs. 7, 12.

1999a Miliammina obliqua Heron-Allen and Earland; Hayward, Grenfell, Reid and Hayward, p. 82, pl. 1, figs. 7, 8.

2005 Miliammina obliqua Heron-Allen and Earland; Horton, Whittaker, Thomson, Hardbattle, Kemp, Woodroffe and Wright, p. 3, pl. 1, fig. 2.

2006 Glomospira sp. Debenay and Luan: pl. 1, fig. 9.

Morphological description. Broadly ovate, quinqueloculine test with early chambers oblique to main axis; thin wall composed of well-cemented fine silt grains, with a smoothly finished, light brown shinning surface; aperture is an interio-marginal arch (Figure 2.27); smaller than M. fusca.

Occurrence. Reported for the first time in Guadiana, where it is common, with higher incidence in winter, at middle elevations of the northernmost positions and at upper elevations with a more confined position.

Remarks. Strong morphological similarities with $M$. fusca may prevent accurate identification, not only in Portuguese estuarine systems, but also worldwide; rarely mentioned in the literature.

Family TROCHAMMINIDAE Schwager, 1877

Genus ARENOPARRELLA Andersen, 1951

Arenoparrella mexicana (Kornfeld, 1931)

Figure 2.29-2.30

1931 Trochammina inflata (Montagu) var. mexicana Kornfeld: p. 86, pl. 13, fig. 5.

1957 Arenoparrella mexicana (Kornfeld); Todd and Bronnimann, p. 30, pl. 4, figs. 23, 24.

1981 Arenoparrella mexicana (Kornfeld); Haynes, p. 104, pl. 6.10, fig. 12.

1991 Arenoparrella mexicana (Kornfeld); Scott, Suter and Kosters, p. 384, pl. 1, figs. 16, 17.

2003 Arenoparrella mexicana (Kornfeld); Duleba and Debenay, p. 77, pl. 1, figs. 11, 12.

2013 Arenoparrella mexicana (Kornfeld); GenBank ID: 164132,

www.ncbi.nlm.nih.gov/Taxonomy/Browser/ wwwtax.cgi? $i d=164132 \mathrm{and} / \mathrm{vl}=0$

Morphological description. Test agglutinated, trochospiral, with supplementary apertures in the apertural face which differentiate the genus from other trochospiral forms.

Occurrence. Rare species in the live fraction, appearing mainly in the mid-low stands of the midupper estuary.

Genus DEUTERAMMINA Brönnimann, 1976

Deuterammina eddystonensis Brönnimann and Whittaker, 1990

Figure 2.31-2.32

1990 Deuterammina eddystonensis Brönnimann and Whittaker: pl. 4, figs. 1-8; pl. 8, fig. 2.

2001 Deuterammina eddystonensis Brönnimann and Whittaker; Debenay, Tsakiridis, Soulard and Grossel, p. 86, pl. 1, figs. 17, 18.

2004 Deuterammina eddystonensis Brönnimann and Whittaker; Diz, Francés, Costas, Souto and Alejo, p. 270, pl. 1, fig. 7.

Morphological description. Wall is thin and agglutinated; the test is low trochospirally enrolled and slightly concavo-convex; chambers increasing in size as added; sutures are radial and the periphery is rounded.

Occurrence. Very rare species in the live fraction (common in dead fraction). 
Genus JADAMMINA Bartenstein and Brand, 1938 Jadammina macrescens (Brady, 1870)

Figures 2.33-2.35 and 3.1-3.2

1870 Trochammina inflata (Montagu) var. macrescens Brady: p. 290, pl. 11, fig. 5.

1938 Jadammina polystoma Bartenstein and Brand: p. 381, fig. 1, 2.

1953 Jadammina polystoma (Brady); Parker, Phleger and Pierson, p. 9, pl. 2, figs. 3537.

1976b Trochammina inflata (Montagu) var. macrescens Brady; Scott, p. 320, pl. 1, figs. 47.

1980 Trochammina macrescens (Brady); Scott and Medioli, p. 44, pl. 3, figs. 1-11.

1990 Trochammina macrescens (Brady); Scott, Schnack, Ferrero, Espinosa and Barbosa, p. 733 , pl. 1, figs. $1,2$.

2003 Trochammina macrescens (Brady); Javaux and Scott, p. 23, figs. 6.14-6.19.

2014 Jadammina macrescens (Brady); GenBank ID: 164128, www.ncbi.nlm.nih.gov/Taxonomy/Browser/ wwwtax.cgi?id=164128andlvl=0

Morphological description. Test a flattened trochospiral, that tends to be nearly planispiral in the adult; chambers increasing gradually in size as they are added, sutures radial to slightly curved, periphery rounded; wall finely and sparsely agglutinated on a proteinaceous base; imperforate; the primary aperture is a low interiomarginal equatorial slit, with one or more supplementary areal openings in the lower portion of the apertural face, each bordered by a projecting lip (Figure 3.1-2).

Occurrence. Indigenous species in the modern estuary; the most ubiquitous agglutinated species, occurring along the entire estuary, but with an optimum of occurrence at the marine estuary, in the most elevated positions of the marsh, where the assemblages are almost exclusively (and in some cases, exclusively) composed of $\mathrm{J}$. macrescens. This species exhibits uncommonly high densities in some places, surpassing 65,000 individuals/20 cc in sample LG1 (confined environment) in winter; dominant in both winter and summer, seems to be better adapted to winter conditions.

Genus LEPIDODEUTERAMMINA Brönnimann and Whittaker, 1983

Lepidodeuterammina plymouthensis Brönnimann and Whittaker, 1990

Figure 3.3-3.4

1974 Trochammina rotaliformis (Wright); Lévy, Mathieu, Poignant, Rosset-Molinier and Rouvillois, p. 128, pl. 1, figs. 4, 5.

1981 Trochammina rotaliformis (Wright); Todd and Low, p. 18.

1990 Lepidodeuterammina plymouthensis Brönnimann and Whittaker: p. 117-118, pl. 3, figs. 1-14.

2004 Lepidodeuterammina plymouthensis Brönnimann and Whittaker; Martins and Gomes, p. 31, fig. 2.13.

Morphological description. The wall is thin and agglutinated; test is low trochospirally enrolled and concavo-convex; sutures are radial and the periphery is rounded.

Occurrence. Very rare in the living assemblages.

Lepidodeuterammina ochracea (Williamson, 1858) Figure 3.5-3.8

1858 Rotalina ochracea Williamson: p. 55, pl. 4, fig. 112; pl. 5, fig. 113.

1865 Trochammina squamata Parker and Jones: p. 407, pl. 15, figs. 30, 31.

1920 Trochammina ochracea (Williamson); Cushman, p. 75, pl. 15, fig. 3.

1952 Trochammina squamata Parker and Jones; Parker, p. 460, pl. 3, fig. 4.

1954 Trochammina ochracea (Williamson); Boltovskoy, p. 265, pl. 22, fig. 5.

1962 Trochammina ochracea (Williamson); Closs and Madeira, pl. 2B, fig. 8.

1971 Trochammina ochracea (Williamson); Murray, p. 37 , pl. 11 , figs. 1-5.

1980 Trochammina ochracea (Williamson); Scott and Medioli, p. 45, pl. 4, figs. 4, 5.

1987 Lepidodeuterammina ochracea (Williamson); Loeblich and Tappan, p. 127, pl. 135, figs. 10-14.

2004 Lepidodeuterammina ochracea (Williamson); Martins and Gomes, p. 29, fig. 2.12.

2005 Trochammina ochracea (Williamson); Barbosa, Scott, Seoane and Turcq, p. 40, pl. 2, figs. 16-20.

Morphological description. The wall is thin, agglutinated and single layered; trochospirally enrolled, very flat and concave ventrally; sutures are radial and the periphery is rounded.

Occurrence. Very rare in the living assemblages. 
Genus PORTATROCHAMMINA Echols, 1971 Portatrochammina sp.

Figure 3.9-3.10

Morphological description. Agglutinated test, trochospirally enrolled, with few, gradually enlarging chambers per whorl; periphery is rounded; wall thin, agglutinated light mineralogical material (transparent).

Occurrence. Very rare in the living assemblages.

Genus SIPHOTROCHAMMINA Saunders, 1957 Siphotrochammina sp.

Figure 3.11-3.13

1995 Trochammnina inflata Montagu 1808; 'Sipho' type, Scott, Hasegawa, Saito, Ito and Collins, p. 294, figs. 6.11, 6.13-6.17.

Morphological description. Test a low trochospiral, chambers ovate, increasing gradually in size as added, sutures gently curved, periphery rounded; wall light brown in color, finely and sparsely agglutinated on a proteinaceous base, the early whorl darker brown and with very little agglutinated material; aperture interiomarginal, at the end of a siphon-like lobe projecting from the umbilical margin of the chamber and directed forward (Loeblich and Tappan, 1987). Although not recognizable through binocular microscope observation, the SEM images of the two photographed specimens (Figure 3.11-12) exhibit a well defined, dorsal, inter-cameral foramen. As far as we know, this characteristic is not documented elsewhere and more photographs should be taken to confirm this morphological characteristic.

Occurrence. Common species in the modern estuary, with a well-defined position along the north-south gradient, appearing (live and dead) only in the northernmost samples (from Aouro upstream).

Genus TIPHOTROCHA Saunders, 1957

Tiphotrocha comprimata (Cushman and Brönnimann, 1948b)

Figure 3.14-3.16

1948b Trochammina comprimata Cushman and Brönnimann: p. 41, pl. 8, figs. 1-3.

1957 Tiphotrocha comprimata (Cushman and Brönnimann); Saunders, p. 20, pl. 4, figs. 1-4.

1980 Tiphotrocha comprimata (Cushman and Brönnimann); Scott and Medioli, p. 44, pl. 5, figs. 1-3.

1991 Tiphotrocha comprimata (Cushman and Brönnimann); Scott, Suter and Kosters, p. 388 , pl. 2, figs. 5,6 .
2004 Tiphotrocha comprimata (Cushman and Brönnimann); Edwards, Wright and van de Plassche, p. 15, pl. 1, figs. 12, 13.

Morphological description. Agglutinated test, trochospirally enrolled, flattened, with ventral side slightly concave; with few gradually enlarging chambers per whorl; periphery is rounded; wall thin; siphon-like extension to the aperture in the umbilical area.

Occurrence. Rare in the living assemblages.

Genus TROCHAMMINA Parker and Jones, 1859 Trochammina inflata (Montagu, 1808)

Figure 3.17-3.21

1808 Nautilus inflatus Montagu: p. 81, pl. 18, fig. 3.

1858 Rotalina inflata (Montagu); Williamson, p. 50, pl. 4, figs. 93, 94.

1952 Trochammina inflata (Montagu); Parker, p. 459, pl. 3, fig. 1.

1957 Siphotrochammina lobata Saunders: p. 9, pl. 3, figs. 1, 2.

1977 Siphotrochammina elegans Zaninetti, Brönnimann, Beurlen and Moura: pl. 2, figs. 8, 10, 11.

1990 Trochammina inflata (Montagu); Scott, Schnack, Ferrero, Espinosa and Barbosa, p. 733 , pl. 1, fig. 3.

2005 Trochammina inflata (Montagu); Horton, Whittaker, Thomson, Hardbattle, Kemp, Woodroffe and Wright, p. 3, pl. 1, fig 4.

Morphological description. Agglutinated test, trochospirally enrolled, chambers rather inflated, increasing in size gradually; aperture a low arch with a bordering lip; smoothly agglutinated.

Occurrence. Dominant in the living assemblages of the modern estuary; closely related to J. macrescens, occurring together in almost all the samples, although it has higher abundances in middle elevations ( 0.2 to $0.8 \mathrm{~m}$ above MSL at samples E1, LG2 and FB2) where J. macrescens abundance starts to decrease and species diversity starts to increase; like $J$. macrescens, it is more common in winter.

Remarks. This taxon is the type species of the genus Trochammina; perhaps the best known and most distinctive of all the endemic marsh species, as well as being one of the earliest species ever described (Scott et al., 2001); the specimens found in Guadiana often present a proteinaceous umbilical tube (Figure 3.18), covered with fine sediment, the purpose of which is unknown. 
Order TEXTULARIIDA Mikhalevich, 1980

Family EGGERELLIDAE Cushman, 1937

Genus EGGERELLOIDES Haynes, 1973

Eggerelloides scaber (Williamson, 1858)

Figure 3.22

1858 Bulimina scabra Williamson: p. 65, pl. 5, figs. 136, 137.

1960 Eggerella scabra (Williamson); Hofker, p. 236, pl. A, figs. 11, 12.

1971 Eggerella scabra (Williamson); Murray, p. 45, pl. 15, figs. 1-6.

1987 Eggerelloides scabrus (Williamson); Loeblich and Tappan, p. 48, pl. 189, figs. 5-7.

1994 Eggerelloides scaber (Williamson); Jones, p. 52 , pl. 47 , figs. $15-17$.

1995 Eggerella scabra (Williamson); Lévy, Mathieu, Poignant, Rosset-Moulinier, Ubaldo and Lebreiro, p. 19, pl. 2, fig. 9.

2004 Eggerelloides scaber (Williamson); Mendes, Gonzalez, Dias, Lobo and Martins, p. 178, pl. 1, fig. 3.

2012 Eggerelloides scabrus (Williamson); Milker and Schmiedl, p. 37, fig. 10.9.

2014 Eggerelloides scaber (Williamson); GenBank ID: 160331,

www.ncbi.nlm.nih.gov/Taxonomy/Browser/ wwwtax.cgi?id=160331 andlvl=0

Morphological description. Agglutinated, oblong test; initial part is trochospirally arranged but is reduced to triserial in the adult; chambers gradually increasing in size as added, so the last whorl commonly forms half the length of the test; the aperture is an interiomarginal arch in the center of the apertural face; coarsely agglutinated wall.

Occurrence. Rare species in the living assemblage but abundant in the dead assemblage; occurs mainly at the lower reaches of the estuary, at the lower stands of the marsh; more abundant in winter.

Remarks. The juvenile specimens can be easily confused with other Eggerella species.

Family TEXTULARIIDAE Ehrenberg, 1838

Genus TEXTULARIA Defrance, 1824

Textularia earlandi Parker, 1952

Figure 3.23-3.25

1933 Textularia tenuissima Earland: p. 95, pl. 3, figs. 21-30.

1952 Textularia earlandi Parker: p. 458, pl. 2, figs. 4-5.
1962 Textularia earlandi Parker; Closs and Madeira, p. 15, est. 3, figs. 6-7; 43, est. 7 , fig. 5 .

1995 Textularia earlandi Parker; Lévy, Mathieu, Poignant, Rosset-Moulinier, Ubaldo and Lebreiro, p. 20, pl. 3, fig. 4.

2004 Spiroplectinella earlandi (Parker); Martins and Gomes, p. 21, fig. 2.7.

2007 Textularia porrecta (Brady, 1884); Duchemin, Fontanier, Jorissen, Barras and Griveaud, p. 28, pl. 1, fig. 8.

Morphological description. Test agglutinated, chambers biserially arranged, laterally compressed; aperture is a simple arch at the base of the last chamber (Figure 3.25).

Occurrence. Rare species, preferring the lower stands of the marsh.

Family VALVULAMMINIDAE Loeblich and Tappan, 1986

Genus DISCORINOPSIS (Cole, 1941)

Discorinopsis aguayoi (Bermúdez, 1935)

Figure 3.26-3.29

1935 Discorbis aguayoi Bermúdez: p. 204, pl. 15, figs. 10-14.

1948b Discorinopsis vadescens Cushman and Brönnimann: p. 20, pl. 4, figs. 9, 10.

1953 Discorinopsis aguayoi (Bermúdez); Parker, Phleger and Pierson, p. 7, pl. 4, figs. 23, 24.

1957 Discorbis? aguayoi Bermúdez; Todd and Brönnimann: pl. 9, fig. 24.

1963 Trichohyalus aguayoi (Bermúdez); Bermúdez and Seiglie, p. 176, pl. 26, fig. 4.

1971 Discorinopsis aguayoi (Bermúdez); Bock, p. 50 , pl. 18, fig. 42 .

1979 Discorinopsis aguayoi (Bermúdez); Scott, Piper and Panagos, p. 257, pl. 16, figs. 1, 2.

1998b Discorinopsis aguayoi (Bermúdez); Debenay, Eichler, Duleba, Bonetti and Eichler-Coelho, p. 80, pl. IV, figs. 24, 25.

2003 Discorinopsis aguayoi (Bermúdez); Javaux and Scott, p. 14, figs. 6.1, 6.2.

Morphological description. Test with low trochospiral coil, with about five chambers in the first whorl; the increased height of the spire results in an auriculate test, spiral side strongly convex, umbilical side flattened to concave with broad umbilicus; sutures strongly curved in spiral side, nearly radial on the umbilical side; wall agglutinated of calcareous particles. 
Occurrence. Species of narrow distribution, occurring with $J$. macrescens and $T$. inflata in significant abundances $(11.9 \%)$ during winter. In the living assemblage, its occurrence seems limited to confined sites of the lower estuary (LG and E1), at low to middle elevations where vegetation occurs.

Remarks. In Guadiana environments $D$. aguayoi is epiphytic, found strongly attached to vegetal structures.

Order BULIMINIDA Fursenko, 1958

Family BOLIVINIDAE Glaessner, 1937

Genus BOLIVINA d'Orbigny, 1839b

Bolivina ordinaria Phleger and Parker, 1952, new name

Figure 4.1-4.4

1952 Bolivina ordinaria Phleger and Parker: $p$. 14, pl. 7, figs. 4-6.

1980 Bolivina ordinaria Phleger and Parker; Boltovskoy, Giussaani, Watanabe and Wright, p. 18, pl. 3, figs. 1-3.

2001 Bolivina variabilis (Williamson, 1858); Debenay, Tsakiridis, Soulard and Grossel, pl. 4, figs. 3, 4 .

2004 Bolivina dilatata (Reuss, 1850); Duijnstee, de Lugt, Noordegraaf and van der Zwaan, p. 145 , pl. I.

2004 Brizalina britannica (Macfadyen, 1942); Leorri and Cearreta, p. 93, pl. 1, fig. 9.

2004 Bolivina pseudoplicata Heron-Allen and Earland, 1930; Diz, Francés, Costas, Souto and Alejo, p. 273, pl. 2, fig. 4.

2004 Bolivina ordinaria Phleger and Parker; Martins and Gomes, p. 90, fig. 2.53.

2008 Brizalina spathulata (Williamson, 1858); Diz and Francés, p. 184, pl. 1, figs. 8-10.

2012 Bolivina ordinaria Phleger and Parker; Mendes, Dias, Schönfeld and Ferreira, $p$. 22, fig. 2.8.

Morphological description. Calcareous wall; test small, compressed, tapering regularly throughout to subacute initial end, slightly ovate at apertural end; chambers increasing gradually as added, narrow, seven to ten pairs in adult; sutures depressed, broad and curved; wall smooth, distinctly perforate; aperture a narrow loop at the base of the apertural face, bordered on one margin by a thickened and imperforated rim.

Occurrence. Dominant species in winter, associated with $A$. aberdoveyensis and $H$. germanica, at low-middle stands of the marsh. In summer it is less frequent and less abundant.
Bolivina cf. variabilis (Williamson, 1858)

1858 cf. Textularia variabilis Williamson: p. 76, pl. 6, figs. 162, 163.

1971 cf. Brizalina variabilis (Williamson); Murray, p. 113 , pl. 46 , figs. 1-3.

2005 cf. Bolivina variabilis (Williamson); Debenay, Millet and Angelidis, p. 336, pl. 3, fig. 4.

2012 cf. Bolivina variabilis (Williamson); Milker and Schmiedl, p. 81, figs. 19.25, 19.26.

2014 cf. Bolivina variabilis (Williamson); GenBank ID: 212447, www.ncbi.nlm.nih.gov/Taxonomy/Browser/ wwwtax.cgi $\mathrm{id}=212447$ and $l v \mathrm{l}=0$

Morphological description. The wall is calcareous; test elongate, compressed, tapering regularly throughout to subacute initial end; numerous chambers increasing gradually as added; sutures depressed, straight and oblique; wall rough, strongly perforate over full width of chambers; aperture a narrow loop at the base of the apertural face, bordered on one margin by a thickened and imperforated rim.

Occurrence. Accessory species, occurring only at LG site, a tidal lagoon at the estuary mouth.

Family BULIMINELLIDAE Hofker, 1951

Genus BULIMINELLA Cushman, 1911

Buliminella elegantissima (d'Orbigny, 1839b)

Figure 4.5

1839b Bulimina elegantissima d'Orbigny: p. 51, pl. 7, figs. 13, 14.

1953 Buliminella elegatissima (d' Orbigny); Parker, Phleger and Pierson, p. 6, pl. 4, figs. 8, 9.

1971 Buliminella elegatissima (d' Orbigny); Murray, p. 105 , pl. 42 , figs. 1-4.

1980 Buliminella elegatissima (d' Orbigny); Scott, Schafer and Medioli, p. 226, pl. 3, figs. 1, 2.

1994 Buliminella elegatissima (d' Orbigny); Jones, p. 55, pl. 50, figs. 20-22.

2003 Buliminella elegatissima (d' Orbigny); Duleba and Debenay, p. 77, pl. 2, fig. 3.

2014 Buliminella elegatissima (d' Orbigny); GenBank ID: 379345, www.ncbi.nlm.nih.gov/Taxonomy/Browser/ wwwtax.cgi? id $=379345$ andlvl $=0$

Morphological description. The test is coiled in a high trochospire of many chambers; only two to three whorls oblongs are developed, well separated by depressed sutures; chambers are numer- 
ous, very narrow and very oblique; the radial calcite wall is perforate except around the aperture. Occurrence. Very rare species, occurring mainly in lower reaches of the estuary.

Order MILIOLIDA Delage and Herouard, 1896

Family CORNUSPIRIDAE Schultze, 1854

Genus CORNUSPIRA Schultze, 1854

Cornuspira involvens (Reuss, 1850)

Figure 4.6-4.7

1850 Operculina involvens Reuss: p. 370 , pl. 46, fig. 20.

1884 Cornuspira involvens (Reuss); Brady, p. 200, pl. 11, figs. 1-3.

1917 Cornuspira involvens (Reuss); Cushman, p. 25, pl. 1, fig. 2; pl. 2, fig. 2; text figs. 2, 3.

1929 Cornuspira involvens (Reuss); Cushman, p. 80 , pl. 20 , figs. 6,8 .

1994 Cornuspira involvens (Reuss); Jones, p. 26, pl. 11, figs. 1-3.

2003 Cornuspira involvens (Reuss); Murray, p. 15, fig. 4.5 .

2012 Cornuspira involvens (Reuss); Milker and Schmiedl, p. 44, fig. 12.1

Morphological description. Wall is calcareous, porcelaneous and imperforate, with smooth surface; test free, discoidal, circular in outline and flattened; the proloculus is followed by a second enrolled and undivided tube that gradually increases in size; aperture is at the end of the tube.

Occurrence. Very rare species.

Miliolid sp.1

Figure 4.8-4.10

Occurrence. Accessory species, predominant at the lower reaches of the estuary.

Miliolid sp.2

Figure 4.11-4.13

Occurrence. Accessory species, with narrow occurrence; recorded only in winter.

Miliolid sp. 3

Figure 4.14-4.16

Occurrence. Dominant species; predominant in winter, mainly at the lower reaches of the estuary.

Miliolid sp.4

Figure 4.17-4.18

Occurrence. Accessory species, predominant mainly at the lower reaches of the estuary.
Miliolid sp.5

Figure 4.19-4.21

Occurrence. Accessory species, predominant mainly at the lower reaches of the estuary; recorded only in summer.

Miliolid sp.6

Figure 4.22-4.23

Occurrence. Rare species, with narrow distribution (LG site); recorded only in winter.

Miliolid sp.9

Figure 4.24-4.26

Occurrence. Rare species, with narrow distribution (LG site); recorded only in winter.

Miliolid sp.10

Figure 4.27-4.29

Occurrence. Rare species, with narrow distribution (LG site); recorded only in winter.

Order ROBERTINIDA Loeblich and Tappan, 1984

Family CERATOBULIMINIDAE Cushman, 1927

Genus LAMARCKINA Berthelin, 1881

Lamarckina haliotidea (Heron-Allen and Earland, 1911)

Figure 5.1

1911 Pulvinulina haliotidea Heron-Allen and Earland: p. 338, pl. 11, figs. 6-11.

1971 Lamarckina haliotidea (Heron-Allen and Earland); Murray, p. 205, pl. 86, figs. 1-6.

2004 Lamarckina haliotidea (Heron-Allen and Earland); Martins and Gomes, p. 80, fig. 2.47.

Morphological description. Calcareous wall, test planoconvex or inequally biconvex, trochospiral, coiling dextral, chambers enlarging rapidly and becoming progressively broader and lower; final chamber strongly overlapping; periphery subacute to carinate; wall calcareous, aragonitic, finely perforate; surface smooth and polished on the umbilical side.

Occurrence. Very rare species.

Order ROTALIIDA Delage and Herouard, 1896

Family ASTERIGERINATIDAE Reiss, 1963

Genus ASTERIGERINATA Bermúdez, 1949

Asterigerinata mamilla (Williamson, 1858)

Figure 5.2-5.3

1858 Rotalia mamilla Williamson: p. 54, pl. 4, figs. 109-111.

1971 Asterigerinata mamilla (Williamson); Murray, p. 141, pl. 59, figs. 1-6.

1974 Discorbis mamilla (Williamson); Colom, p. 124, fig. 21, f-i and o-s. 
1995 Asterigerinata mamilla (Williamson); Lévy, Mathieu, Poignant, Rosset-Moulinier, Ubaldo and Lebreiro, p. 46, pl. 10, fig. 10.

2004 Eoeponidella pulchella (Parker, 1952); Diz, Francés, Costas, Souto and Alejo, p. 273, pl. 2, fig. 14.

2012 Asterigerinata mamilla (Williamson); Milker and Schmiedl, p. 111, figs. 24.21-24.24.

Morphological description. Calcareous wall, test planoconvex, trochospiral and conical in peripheral view; spiral side is convex and evolute; umbilical side is involute; chambers increasing rapidly in breadth and becoming broad; sutures are curved and oblique; on the umbilical side only the five chambers of the final whorl are visible; sutures are slightly depressed; both sides are perforate with larger pores on the spiral; aperture is a low interiomarginal, umbilical arch at the base of the final chamber.

Occurrence. Common species (10-20\%) in the biocenosis; more abundant at the lower estuary; higher densities during winter.

Family DISCORBIDAE Ehrenberg, 1838 Genus DISCORBIS Lamarck, 1804

Discorbis sp.

Figure 5.4-5.5

1994 Bucella frigida (Cushman, 1921); Hayward and Hollis, p. 212, pl. 3, figs. 11-13.

1999a Ammonia pustulosa (Albani and Barbero, 1982); Hayward, Grenfell, Reid and Hayward, p. 163, pl. 16, figs. 4-6.

Occurrence. Rare species, occurring only in summer, at the lower reaches of the estuary.

Family HELENINIDAE

Genus HELENINA Saunders, 1961

Helenina anderseni (Warren, 1957)

Figure 5.6-5.7

1957 Pseudoeponides anderseni Warren: p. 39, pl. 4, figs. 12-15.

1961 Helenina anderseni (Warren); Saunders, p. 148 ;

1980 Helenina anderseni (Warren); Scott and Medioli, p. 40, pl. 5, figs. 10, 11.

1991 Helenina anderseni (Warren); Scott, Suter and Kosters, p. 385, pl. 2, figs. 19, 20.

1999a Helenina anderseni (Warren); Hayward Grenfell, Reid and Hayward, p. 138, pl. 10, figs. 1-3.

2003 Helenina anderseni (Warren); Javaux and Scott, p. 16, figs. $6.3,6.4$.
Morphological description. Test calcareous, finely perforate; surface smooth; low trochospiral, both sides flattened; chambers enlarging gradually; sutures curved, oblique, depressed, on the opposite side the somewhat produced umbilical flaps of successive chambers overlap to close the umbilicus; aperture an extraumbilical interiomarginal slit, bordered by a lip; supplementary sutural apertural slits present on both sides.

Occurrence. Rare species, with a narrow distribution restricted to the estuary's lower reaches.

Family NONIONIDAE

Genus HAYNESINA Banner and Culver, 1978

Haynesina depressula (Walker and Jacob, 1798)

Figure 5.8

1798 Nautilus depressulus Walker and Jacob: $p$. 641, pl. 14, fig. 33.

1994 Haynesina depressula (Walker and Jacob); Hayward and Hollis, p. 217, pl. 5, figs. 13-16.

2012 Haynesina depressula (Walker and Jacob); Milker and Schmiedl, p. 109, figs. 25.17, 25.18.

Morphological description. The wall is calcareous, planispiral, circular in outline and biumbilicate with narrow and depressed umbilici in peripheral view; the sutures are radial, backward curved; about eight to ten chambers per whorl, enlarging gradually as added; the umbilical region is filled with large pustules; test surface is smooth.

Occurrence. Rare species.

Haynesina germanica (Ehrenberg, 1840) Figure 5.9

1840 Nonionina germanica Ehrenberg: p. 23, pl. 2, fig. 1a-g.

1930 Nonion germanicum (Ehrenberg); Cushman, p. 8, 9, pl. 3, fig. 5 .

1959 Protelphidium tisburyense (Butcher, 1948); Parker and Athearn, p. 342, pl. 50, figs. 26, 32.

1980 Protelphidium orbiculare (Brady, 1881); Scott and Medioli, p. 43, pl. 5 fig. 7.

1990 Haynesina germanica (Ehrenberg); Lee, pl. 5, fig. 20.

2000 Haynesina germanica (Ehrenberg); Langer, p. 643, figs. 1A, B, C.

2007 Haynesina germanica (Ehrenberg); Cearreta, Alday, Freitas and Andrade, p. 134, pl. 1, fig. 2.

2014 Haynesina germanica (Ehrenberg); GenBank, ID: 45993, 
www.ncbi.nlm.nih.gov/Taxonomy/Browser/ wwwtax.cgi?id=45993andlvl=0

Morphological description. The wall is calcareous, planispiral, circular in outline, and biumbilicate with narrow and depressed umbilici in peripheral view; the sutures are radial, backward curved; about eight to ten chambers per whorl, enlarging gradually as added; the umbilical region is filled with pustules; the periphery is subrounded and the test surface is smooth.

Occurrence. Dominant and constant species in Guadiana Estuary, predominant at the middle and lower elevations of the marsh; strongly associated with $A$. aberdoveyensis.

Family ELPHIDIIDAE Galloway, 1933

Genus ELPHIDIUM de Montfort, 1808

Elphidium advenum (Cushman, 1922)

Figure 5.10

1922 Polystomella advena Cushman: p. 56, pl. 9, figs. 11, 12.

1930 Elphidium advenum (Cushman); Cushman, p. 25, pl. 10, figs. 1, 2.

1994 Elphidium advenum (Cushman); Jones, p. 108, pl. 110, fig. 1.

2006 Elphidium advenum (Cushman); Debenay and Luan, pl. 2, fig. 46.

Morphological description. The wall is calcareous, planispiral enrolled; peripheral outline slightly lobate, slightly compressed, biconvex profile; periphery acute, with a strong rounded keel; 12 to 15 chambers in final whorl; sides flattened to slightly concave; sutures flush to slightly depressed, moderately curved backwards; flattened boss in the umbilicus; wall opaque white.

Occurrence. rare species in Guadiana Estuary; only recorded in summer, at the estuary lower reaches.

Elphidium excavatum (Terquem, 1875)

Figure 5.11

1858 Polystomella umbilicatula Williamsom: $p$. 42, pl. 3, fig. 81.

1875 Polystomella excavata Terquem: p. 25, pl. 2, fig. 2a-f.

1952 Elphidium excavatum (Terquem); Parker, p. 448 , pl. 3, fig. 13.

1994 Elphidium excavatum (Terquem) f. excavatum (Terquem); Hayward and Hollis, p. 214, pl. 5, figs. 1-5.

1998b Elphidium excavatum (Terquem); Debenay, Eichler, Duleba, Bonetti and Eichler-Coelho, p. 80, pl. IV, figs. 9, 10.
2003 Cribroelphidium excavatum (Terquem) f. selseyensis (Heron-Allen and Earland, 1911); Duleba and Debenay, p. 77, pl. 2, fig. 7.

2014 Elphidium excavatum (Terquem); GenBank, ID: 212501,

www.ncbi.nlm.nih.gov/Taxonomy/Browser/ wwwtax.cgi

Morphological description. The wall is calcareous, planispiral enrolled; peripheral outline slightly lobate, rounded in edge view; eight to ten chambers in outer whorl; sutures straight to moderately curved backwards, narrow, extending into umbilical area; umbilicus depressed, covered by numerous papillae.

Occurrence. Rare species in Guadiana Estuary; only recorded at the estuary lower reaches.

Elphidium williamsoni Haynes, 1973

Figure 5.12-5.15

1973 Elphidium williamsoni Haynes: p. 207, pl. 24, fig. 7; pl. 25, figs. 6, 9; pl. 27, figs. 1-3.

1997 Elphidium excavatum (Terquem, 1875) f. williamsoni Haynes; Hayward, Hollis and Grenfell, p. 79, pl. 10, figs. 11-18.

2004 Elphidium williamnsoni Haynes; Leorri and Cearreta, p. 93, pl. 1, fig. 4.

2014 Elphidium williamnsoni Haynes; Pawlowski and Holzmann, forambarcoding.unige.ch/specs/105elphidium-williamsoni

2014 Elphidium williamnsoni Haynes; GenBank, ID: 139273, www.ncbi.nlm.nih.gov/Taxonomy/Browser/ wwwtax.cgi? id=139273andlvl=0

2014 Elphidium williamnsoni Haynes; this study; European Nucleotide Archive (ENA) http:// www.ebi.ac.uk/ena/data/view/LN551930LN551935

Morphological description. The wall is calcareous, planispiral enrolled; test with evenly rounded outline, becoming lobulate in later part; periphery broadly rounded to sub-acute; septal bridges long, evenly spaced and numerous.

Occurrence. Relatively abundant species $(<10 \%)$ in Guadiana lower estuary, mainly during winter.

Elphidium gerthi Van Voorthuysen, 1957

Figure 5.16-5.18

1957 Elphidium gerthi Van Voorthuysen: p. 32, pl. 23, fig. 12. 
1995 Cribrononion gerthi (Van Voorthuysen); Lévy, Mathieu, Poignant, Rosset-Moulinier, Ubaldo and Lebreiro, p. 51, pl. 12, fig. 2.

2004 Cribrononion gerthi (Van Voorthuysen); Martins and Gomes, p. 257-258, fig. 2.152.

2008 Elphidium sp. Diz and Francés: pl. 2, fig. 3.

2012 Elphidium gerthi Van Voorthuysen; Mendes, Dias, Schönfeld and Ferreira, p. 24, fig. 4.8 .

Morphological description. The wall is calcareous; test is planispiral, compressed and slightly evolute; the umbilical area is large and slightly depressed; nine to eleven chambers in the final whorl; sutures depressed, curved close to the periphery, crossed by sutural bridges or retral processes, with several fossettes; the aperture is multiple with several interomarginal arches.

Occurrence. Relatively abundant species (<10\%) in Guadiana estuary, along middle to lower estuary.

Elphidium oceanensis (d'Orbigny, 1826)

Figure 5.19-5.21

1826 Polystomella oceanensis d'Orbigny: $p$. 285.

1948a Cribroelphidium vadescens Cushman and Bronnimann: p. 18, pl. 4, fig. 5.

1951 Elphidium littorale Le Calvez and Le Calvez: p. 251, figs. 5a, 5b.

1971 Elphidium oceanensis (d'Orbigny); Murray, p. 165 , pl. 69 , figs. 1-7.

1982 Elphidium gunteri Cole, 1931; Buzas and Severin, p. 37, pl. 8, fig. 4.

1988 Elphidium oceanensis (d'Orbigny); Cearreta, p. 36, pl. I, fig. 8.

1994 Elphidium gunteri Cole, 1931; Hayward and Hollis, p. 209, pl. 4, figs. 10-12.

2004 Elphidium oceanensis (d'Orbigny); Leorri and Cearreta, p. 78, pl. 1, fig. 5.

2006 Cribroelphidium mirum n. sp. Langer and Schmidt-Sinns: p. 669, figs. 1.1-1.23.

2007 Elphidium oceanensis (d'Orbigny); Cearreta, Alday, Freitas and Andrade, p. 134, pl. I, fig. 3.

Morphological description. The wall is calcareous; test planispiral, involute and inflated with eight to fifteen chambers in outer whorl; periphery broadly rounded, slightly to irregularly lobate; sutures depressed, straight to gently curved; septal bridges irregular in number and degree of development; umbilicus may be slightly depressed or raised due to growth of irregular bosses; tubercular development in sutural pits, umbilical depression and base of apertural face; aperture is an interiomarginal row of arches; wall is coarsely perforate and usually golden brown.

Ocurrence. Has its optimum during summer, being a dominant species at middle and lower elevations ( -0.7 to $1.1 \mathrm{~m}$ in relation to MSL); in terms of distribution range it is almost as eurytopic as Ammonia spp., occupying the entire study range of elevation and latitude.

\section{Elphidium poeyanum (d'Orbigny, 1839a)}

Figure 5.22-5.23

1839a Polystomella poyana d'Orbigny: p. 55, pl. 6, figs. 25, 26.

1930 Elphidium poeyanum (d'Orbigny); Cushman, p. 25, pl. 10, figs. 4, 5 .

1953 Elphidium poeyanum (d'Orbigny); Parker, Phleger and Pierson, p. 9, pl. 3, fig. 26.

1998b Elphidium poeyanum (d'Orbigny); Debenay, Eichler, Duleba, Bonetti and Eichler-Coelho, p. 80, pl. IV, fig. 11.

2001 Cribroelphidium cuvillieri (Lévy, 1966); Debenay, Tsakiridis, Soulard and Grossel, p. 96, pl. 6, fig. 18.

2003 Cribroelphidium poeyanum (d'Orbigny); Duleba and Debenay, p. 77, pl. 2, fig. 8.

2007 Cribroelphidium excavatum (Terquem, 1875); Cearreta, Alday, Freitas and Andrade, p. 134, pl. 1, fig. 7.

2008 Elphidium translucens Natland, 1938; Diz and Francés, p. 185, pl. 2, fig. 2.

Morphological description. The wall is calcareous, planispiral enrolled; test outline circular to slightly lobulate; periphery broadly rounded with no keel; eight to nine slightly inflated chambers per adult whorl, broadly finely to medium perforated; umbilical area small, without tubercles.

Occurrence. Rare species in Guadiana Estuary only found in winter.

Family ROTALIIDAE Ehrenberg, 1839

Genus AMMONIA Brünnich, 1772 Ammonia sp1

Figure 5.24-5.27

Ammonia aberdoveyensis Haynes, 1973

Figure 5.28-5.35

1973 Ammonia aberdoveyensis Haynes: p. 184, fig. 38, nos. 1-7.

1990 Ammonia beccarii (Linné) f. tepida (Cushman, 1926); Walton and Sloan, pl. 1, figs. 1-4; pl. 2, fig. 2.

1995 Ammonia beccarii (Linné, 1758); Yassini and Jones, p. 175, figs. 994-999. 
2004 Ammonia aberdoveyensis Haynes; Hayward, Holzmann, Grenfell, Pawlowski and Triggs, p. 253, pl. II, fig. T2; p. 256, pl. III, fig. T2; p. 258, pl. IV, fig. T2.

2007 Ammonia aberdoveyensis Haynes; Wennrich, Meng and Schmiedl, p. 321, pl. 1, fig. 3.

2014 Ammonia aberdoveyensis Haynes; Pawlowski and Holzmann:

forambarcoding.unige.ch/specs/72-ammonia-aberdoveyensis-t2

2014 Ammonia aberdoveyensis Haynes; this study; European Nucleotide Archive (ENA) http://www.ebi.ac.uk/ena/data/view/

LN551930-LN551935

Morphological description. Small proloculus, test medium-size $(0.3-0.5 \mathrm{~mm})$; whorls medium width on spiral side; moderate inflation, a broadly rounded periphery, six to nine chambers per whorl; small pores and longer radial sutural furrows on the umbilical side than the other 'Ammonias'; little to no secondary calcite, usually with no umbilical boss.

Occurrence. Together with Ammonia sp1, this is the most ubiquitous calcareous species in the modern estuary, being absent only from the most elevated stands of the marsh; its optimum occurrence is in the lower to middle elevations of the lower and middle estuary; its peak of occurrence is observed in summer, especially in the lower elevations where it is always the dominant species; in summer, it is able to migrate farther up the marsh, occupying higher elevation stands; is a dominant element in two of the main assemblages found for Guadiana: in the middle elevations of upstream assemblage, where it is subdominant to $M$. fusca, and in the lower elevations of the lower estuary assemblage, where it is co-dominant with $B$. ordinaria in winter.

Remarks. Found on Mediterranean coasts, France and Italy (Hayward et al., 2004).

\section{ACKNOWLEDGEMENTS}

The authors would like to thank to L. Pereira and P. Santana for technical assistance with field survey and J. Nieto and C. Cantero from Huelva University, for providing excellent MEV photography service. We are also grateful to M. Holzmann, from Geneva University, for kindly accepting our foraminifera in the Foram Barcoding project and for sharing the results and knowledge, and to the Editor P. Polly, to Dr F. Frontalini and one anonymous reviewer, who greatly improved the original manu- script with their advices. The present work was financially supported by the Portuguese Foundation for Science and Technology (FCT) through a PhD grant SFRH/BD/28265/2006.

\section{REFERENCES}

Albani, A. and Barbero, S. 1982. A foraminiferal fauna from the lagoon of Venice, Italy. Journal of Foraminiferal Research, 12:234-241.

Albani, A., Hayward, B.W., and Grenfell, H.R. 2001. Taxomorph: Foraminifera from the South-west Pacific. An inter-active catalogue. University of New South Wales and Australian Biological Resources Study CD-ROM.

Andersen, A.D. 1951. Two new genera of Foraminifera from recent deposits of Louisiana. Journal of Paleontology, 25:31-34.

Andrade, C., Freitas, M.C., Moreno, J., and Craveiro, S.C. 2004. Stratigraphical evidence of late Holocene barrier breaching and extreme storms in lagoonal sediments of Ria Formosa, Algarve, Portugal. Marine Geology, 210:339-362.

Banner, F.T. and Culver, S.J. 1978. Quaternary Haynesina n. gen. and Paleogene Protelphidium Haynes; their morphology, affinities and distribution. Journal of Foraminiferal Research, 8:177-207.

Barbosa, C., Scott, D.B., Seoane, J., and Turcq, B. 2005. Foraminiferal zonations as base lines for Quaternary sea-level fluctuations in south-southeast Brazilian mangroves. Journal of Foraminiferal Research, 35:22-43.

Barros, P. and Candeias, J. 1998. Modelando o Sistema do Estuário do Rio Guadiana, p. 95-96. In Actas do $1^{\circ}$ Simpósio Interdisciplinar de Processos Estuarinos, Universidade do Algarve, Faro.

Bartenstein, H. and Brand, E. 1938. Die foraminiferanfauna des Jade-Gebietes. 1. Jadammina polystoma n.g., n.sp. aus dem Jade-Gebietes (for). Senckenbergiana, 20:381-385.

Bermúdez, P.J. 1935. Foraminiferos de la costa norte de Cuba. Memorias de la Sociedad Cubana de Historia Natural, 9:129-224.

Bermúdez, P.J. 1949. Tertiary smaller foraminifera of the Dominican Republic. Special Publications Cushman Laboratory for Foraminiferal Research, 25:1-322.

Bermúdez, P.J. and Seiglie, G.A. 1963. Estudio sistemático de los foraminiferos del golfo de Cariaco. Boletin de Institute de Oceanographica de Universitad de Oriente, 2:3-253.

Berthelin, G. 1881. Coup d'oeil sur la faune rhizopodique du Calcaire Grossier Inférieur de la Marne, p. 553559. In Compte rendu de l'Association Française pour l'Avancement des Sciences, 9th sess. (Reims, 1880).

Bock, W.D. 1971. A handbook of the benthonic foraminifera of Florida Bay and adjacent waters. Miami Geological Society, Memoir, 1:1-92. 
Boltovskoy, E. 1954. Foraminíferos del Golfo San Jorge. Revista del Instituto Nacional de Investigación de las Ciencias Naturales y Museo Argentino de Ciencias Naturales "Bernardino Rivadavia", Ciencias Geológicas, tomo III, Buenos Aires, 3:79-246.

Boltovskoy, E., Giussaani, G., Watanabe, S., and Wright, R. 1980. Atlas of Benthic Shelf Foraminifera of the Southwest Atlantic. Dr. W. Publishers, The Hague, Boston-London.

Boltovskoy, E. and Totah, V. 1985. Diversity, similarity and dominance in benthic foraminiferal fauna along one transect of the Argentine shelf. Revue de Micropaléntologie, 28:23-31.

Boski, T., Camacho, S., Moura, D., Fletcher, W., Wilamowski, A., Veiga-Pires C., Correia, V., Loureiro, C., and Santana, P. 2008. Chronology of the sedimentary processes during the post-glacial sea level rise in two estuaries of the Algarve coast, southern Portugal. Estuarine, Coastal and Shelf Science, 77:230244.

Boski, T., Moura, D., Veiga-Pires, C., Camacho, S., Duarte, D., Scott, D.B., and Fernandes, S. 2002. Postglacial sea-level rise and sedimentary response in the Guadiana Estuary, Portugal/Spain border. Sedimentary Geology, 150:103-122.

Boski, T., Sousa, C., Loureiro, C., Limpo, S., Albardeiro, L., Camacho, S., Pereira, L., Amaral, A., Nieto, J., Rodriguez, J., Salas, L, Gonzalez-Villa, F., Pérez, J., Simonson, W., and Lima, A. 2006. GUADID, version 1.1, How an estuary works? Didactic Application: Project MEGASIG, INTERREG III, AISBN: 978-98995636-0-5.

Brady, H.B. 1870. Part II. Analysis and description of foraminifera. Annals and Magazine of Natural History, 4:273-309.

Brady, H.B. 1881. On some arctic foraminifera from soundings obtained on the Austro-Hungarian North Polar Expedition of 1872-76. Annals and Magazine of Natural History, 8:393-418.

Brady, H.B. 1884. Report on the foraminifera dredged by H. M. S. Challenger during the years 1873-1876. In Report on the scientific results of the voyage of H.M.S. Challenger during the years 1873-1876. Zoology, 9, London.

Brönnimann, P. 1976. Two new genera of Recent Trochamminidae (Foraminiferida). Archives des Sciences, Genève, 29:215-218.

Brönnimann, P. and Keij, A.J. 1986. Agglutinated foraminifera (Lituolacea and Trochamminacea) from brackish waters of the State of Brunei and of Sabah, Malaysia, northwest Borneo. Revue de Paléobiologie, 5:11-31.

Brönnimann, P. and Whittaker, J.E. 1983. Deuterammina (Lepidodeuterammina) subgen. nov., and a redescription of Rotalina ochracea Williamson (Protozoa: Foraminiferida). Bulletin of the British Museum (Natural History) (Zool.) 45:233-238.
Brönnimann, P. and Whittaker, J.E. 1990. Revision of the Trochamminacea and Remaneicacea of the Plymouth District, S.W. England, described by HeronAllen and Earland (1930), p. 105-137. In Hemleben, C., Kaminski, M.A., Kunt, W., and Scott, D.B. (eds.), Paleoecology, Biostratigraphy, Paleoceanography and Taxonomy of Agglutinated Foraminifera, NATO ASI Series, Kluwer Academic Publishers.

Brönnimann, P. and Whittaker, J.E. 1993. Taxonomic revision of some Recent agglutinated foraminifera from the Malay Archipelago, in the Millett Collection, The Natural History Museum, London. Bulletin of the Natural History Museum (Zool.) 59:107-124.

Brünnich, M.T. 1772. Zoologiae Fundamenta Praelectionibus Academicis. Accomodata Grunde i Dyeloeren. Transaction of the Linnean Society of London, 7:241.

Butcher, W.S. 1948. A new species of Nonion (Foraminifera) from the Woods Hole region: Contributions from the Cushman Laboratory for Foraminifera Research, 24:21-23.

Buzas, M.A., Hayek, L.C., Reed, S.A., and Jett, J.A. 2002. Foraminiferal densities over five years in the Indian River Lagoon, Florida: a model of pulsating patches. Journal of Foraminiferal Research, 32:6892.

Buzas, M. and Severin, K. 1982. Distribution and systematic of foraminifera in the Indian River, Florida. Smithsonian Contributions to the Marine Sciences, 16:1-73.

Calonge, A., Caus, E., and García, J. 2001. Los Foraminíferos: Presente e pasado. Enseñanza de las Ciencias de la Tierra, 9:144-150.

Camacho, S., Moura, D., Connor, S., Boski, T., and Gomes, A. 2014. Geochemical characteristics of sediments along the margins of an atlantic-mediterranean estuary (the Guadiana, Southeast Portugal): spatial and seasonal variations. Journal of Integrated Coastal Zone Management, 14:129-148.

Camacho, S., Moura, D., Connor, S., Scott, D.B., and Boski, T. 2015. Ecological zonation of benthic foraminifera in the lower Guadiana Estuary (southeastern Portugal). Marine Micropaleontology, 114:1-18.

Cavalier-Smith, T. 2010. Kingdoms Protozoa and Chromista and the eozoan root of the eukaryotic tree. Biology Letters, 6:342-345.

Cearreta, A. 1988. Distribution and ecology of benthic foraminifera in the Santoña estuary, Spain: Revista Española de Paleontología, 3:23-38.

Cearreta, A., Alday, M., Freitas, M., and Andrade, C. 2007. Postglacial Foraminifera and Paleoenvironments of the Melides Lagoon (SW Portugal): Towards a Regional Model of Coastal Evolution. Journal of Foraminiferal Research, 37:125-135.

Cearreta, A., Alday, M., Freitas, M., Andrade, C., and Cruces, A. 2002. Modern foraminiferal record of alternating conditions in the Santo André Lagoon, SW Portugal. Hydrobiologia, 475/476:21-27. 
Chaster, G.W. 1892. Report upon the foraminifera of the Southport Society of Natural Sciences District. First Report Southport Society of Natural Science (18901891), appendix, 54-72.

Closs, D. and Madeira, M. 1962. Tecamebas e foraminíferos do Arroio Chuí (Santa Vitória do Palmar, R. Grande do Sul, Brasil). Heringia (Zoologia), Séries Científicas do Museu Rio-Grandense de Ciências Naturais. Porto Alegre, Brasil, 19:1-43.

Cole, W.S. 1941. Stratigraphic and paleontologic studies of wells in Florida. Florida Geological Survey Bulletin, 19:1-91.

Colom, G. 1974. Foraminiferos Ibericos. Intruducción al Estudio de las Especies Bentónicas Recientes. Investigacion Pesquera, Consejo Superior de Investigaciones Científicas. Patrono Juán de la Cierva, Barcelona.

Confederación Hidrográfica del Guadiana 2012. Geoportal - Catálogo de metadados. Available online at www.chguadiana.es/Geoportal/. Consulted during April 2012.

Cushman, J.A. 1910. A monograph of the foraminifera of the North Pacific Ocean, Part 1: Astrorhizidae and Lituolidae. Smithsonian Institute. Bulletin of the United States National Museum, 71(1):1-134.

Cushman, J.A. 1911. A monograph of the foraminifera of the North Pacific Ocean, Part 2: Textularidae. Smithsonian Institute. Bulletin of the United States National Museum, 71(2):1-108.

Cushman, J.A. 1917. A monograph of the foraminifera of the North Pacific Ocean, Part 6: Miliolidae. Smithsonian Institute. Bulletin of the United States National Museum, 71(6):1-108.

Cushman, J.A. 1920. The foraminifera of the Atlantic Ocean, Part 2: Lituolidae. Smithsonian Institute. United States National Museum Bulletin, 104(2):1111.

Cushman, J.A. 1922. Shallow water foraminifera of the Tortugas region. Carnegie Institution of Washington, Department of Marine Biology, 311:1-85.

Cushman, J.A. 1926. Recent foraminifera from Porto Rico: Publications of the Carnegie Institution of Washington, 342:73-84.

Cushman, J.A. 1927. An outline of a re-classification of the foraminifera. Contributions from the Cushman Laboratory for Foraminiferal Research, 3:1-105.

Cushman, J.A. 1929. The foraminifera of the Atlantic Ocean, Part 6: Miliolidae Ophthalmidiidae, Fischerinidae. Smithsonian Institute. United States National Museum Bulletin, 104(6):1-129.

Cushman, J.A. 1930. The foraminifera of the Atlantic Ocean, Part 7: Nonionidae, Camerinidae, Peneroplidae, and Alveolinellidae. Smithsonian Institute. United States National Museum Bulletin, 104(7):179.

Cushman, J.A. 1933. Foraminifera their classification and economic use. Special Publications Cushman Laboratory for Foraminiferal Research, 4:1-349.
Cushman, J.A. 1937. A monograph of the foraminiferal family Valvulinidae. Special Publications Cushman Laboratory for Foraminiferal Research, 8:1-210.

Cushman, J.A. and Brönnimann, P. 1948a. Some new genera and species of Foraminifera from brackish water of Trinidad. Contribution to Cushman Laboratory of Foraminifera Research, 24:15-21.

Cushman, J.A. and Brönnimann, P. 1948b. Additional new species of arenaceous foraminifera from shallow waters of Trinidad. Contribution to Cushman Laboratory of Foraminifera Research, 24:37-42.

Dawson, G.M. 1870. On foraminifera from the Gulf and River St. Lawrence. From the Canadian Naturalist.

Debenay, J.-P., Bénéteau, E., Zhang, J., Stouff, V., Geslin, E., Redois, F., and Fernandez-Gonzalez, M. 1998a. Ammonia beccarii and Ammonia tepida (Foraminifera): morphofunctional arguments for their distinction. Marine Micropaleontology, 34:235-244.

Debenay, J.-P., Bicchi, E., Goubert, E., and Armynot du Châtelet, E. 2006. Spatio-temporal distribution of benthic foraminifera in relation to estuarine dynamics (Vie estuary, Vendée, W France). Estuarine, Coastal and Shelf Science, 67:181-197.

Debenay, J.-P., Carbonel, P., Morzadec-Kerfourn, M.-T., Cazaubon, A., Denèfle, M., and Lézine, A.-M. 2003. Multi-bioindicator study of a small estuary in Vendée (France). Estuarine, Coastal and Shelf Science, 58:843-860.

Debenay, J.-P., Eichler, B.B., Duleba, W., Bonetti, C., and Eichler-Coelho, P. 1998b. Water stratification in coastal lagoons: its influence on foraminiferal assemblages in two Brazilian lagoons. Marine Micropaleontology, 35:67-89.

Debenay, J.-P., Geslin, E., Redois, F., Guillou, J.J., Eichler, B.B., Duleba, W., Bonetti, C., and Luan, B.T. 1998c. Ecological Trends in Foraminiferal Assemblages of Paralic Environments, p. 25-26. In Proceedings of the Meeting and Abstracts of the International Symposium on Foraminifera, Sociedad mexicana de Paleontologia, A.C., Monterrey.

Debenay, J.-P. and Guillou, J.J. 2002. Ecological Transitions Indicated by Foraminiferal Assemblages in Paralic Environments. Estuaries, 25:1107-1120.

Debenay, J.-P., Guillou, J.J., Redois, F., and Geslin, E. 2000. Distribution Trends of Foraminiferal Assemblages in Paralic Environments: a base for using foraminifera as bioindicators, p. 39-67. In Martin, R.E. (ed.), Environmental Micropaleontology. Kluwer Academic, New York.

Debenay, J.-P. and Luan, B. 2006. Foraminiferal assemblages and the confinement index as tools for assessment of saline intrusion and human impact in the Mekong Delta and neighbouring areas (Vietnam). Revue de Micropaléontologie, 49:74-85.

Debenay, J.-P., Millet, B., and Angelidis, M.O. 2005. Relationships between foraminiferal assemblages and hydrodynamics in the Gulf of Kalloni, Greece. Journal of Foraminiferal Research, 35:327-343. 
Debenay, J.-P., Pawlowski, J., and Decrouez, D. 1996. Les Foraminifères Actuels. Masson, Paris.

Debenay, J.-P. and Redois, F. 1997a. Recent Foraminifera of the Northern Continental Shelf of Senegal. Revue de Micropaléontologie, 40:15-38.

Debenay, J.-P. and Redois, F. 1997b. Distribution of the twenty seven dominant species of shelf benthic foraminifers on the continental shelf, north of Dakar (Senegal). Marine Micropaleontology, 29:237-255.

Debenay, J.-P., Tsakiridis, E., Soulard, R., and Grossel, H. 2001. Factors determining the distribution of foraminiferal assemblages in Port Joinville Harbor (lle d'Yeu, France): the influence of pollution. Marine Micropaleontology, 43:75-118.

de Blainville, H.M. 1827. Mémoire sur les Bélemnites, Considérés Zoologiquement et Géologiquement. A Paris, Chez F.G. Levrault, Strasbourg.

Defrance, J.L.M. 1824. Dictionnnaire des Science Naturelles, volume 32. F.G. Levrault, Strasbourg.

Delage, Y. and Herouard, E. 1896. Traité de Zoologie Concrète, Volume I, La Cellule et les Protozoaires. Schleicher Freres, Paris.

Delgado, J., Boski, T., Nieto, J., Pereira, L., Moura, D., Gomes, A., Sousa, C., and García-Tenorio, R. 2012. Sea-level rise and anthropogenic activities recorded in the late Pleistocene/Holocene sedimentary infill of the Guadiana Estuary (SW Iberia). Quaternary Science Reviews, 33:121-141.

de Montfort, D. 1808. Conchyliologie Systematique et Classification Methodique des Coquilles, Volume 1, F. Schoell, Paris.

Dias, J.M.A., Ferreira, Ó., Mendes, I., and Gonzalez, R. 2001. Projecto EMERGE - Estudo multidisciplinar do estuário do Rio Guadiana. Relatório final 3/01. CIACOMAR, Universidade do Algarve, Olhão, Portugal. CD-ROM.

Diz, P. and Francés, G. 2008. Distribution of live benthic foraminifera in the Ría de Vigo (NW Spain). Marine Micropaleontology, 66:165-191.

Diz, P., Francés, G., Costas, S., Souto, C., and Alejo, I. 2004. Distribution of benthic foraminifera in coarse sediment, Ría de Vigo, NW Iberian margin. Journal of Foraminiferal Research, 34:258-275.

d'Orbigny, A. 1826. Tableau méthodique de la classe des Cephalopodes. Annales des Sciences Naturelles, 7:96-169, 245-314.

d'Orbigny, A. 1839a. Foraminifères, $224 \mathrm{pp}$. In de la Sagra, R. (ed.), Histoire Physique, Politique et Naturelle de l'ile de Cuba, Bertrand, A., Paris.

d'Orbigny, A. 1839b. Voyage dans l'Amérique Méridionale (le Brésil, la République Orientale de l'Uruguay, la République Argentine, la Patagonie, la République du Chili, la République de Bolivia, la République du Pérou) éxécut, pendant les années 1826, 1827, 1832 et 1833 - Foraminifères, Part 5(5), Bertrand, Paris; Levrault, Strasbourg.
Duchemin, G., Fontanier, C., Jorissen, F.J., Barras, C., and Griveaud, C. 2007. Living small-sized (63-150 $\mu \mathrm{m})$ foraminifera from mid-shelf to mid-slope environments in the Bay of Biscay. Journal of Foraminiferal Research, 37:12-32.

Duijnstee, I., de Lugt, I., Noordegraaf, V., and van der Zwaan, B. 2004. Temporal variability of foraminiferal densities in the northern Adriatic Sea. Marine Micropaleontology, 50:125-148.

Duleba, W. and Debenay, J.-P. 2003. Hydrodynamic circulation in the estuaries of Estação Ecológica JuréiaItatins, Brazil, inferred from foraminifera and thecamoebian assemblages. Journal of Foraminifera Research, 33:62-93.

Earland, A. 1933. Foraminifera; Part II - South Georgia "Discovery" reports, 7:27-138.

Echols, R.J. 1971. Distribution of Foraminifera in sediments of the Scotia Sea area, Antarctic waters, p. 93168. In Reid, J.L. (ed.), Antarctic oceanology 1. Antarctic Research Series, 15, Washington.

Edwards, R.J., Wright, A.J., and van de Plassche, O. 2004. Surface distribution of salt-marsh foraminifera from Connecticut, USA: modern analogues for highresolution sea level studies. Marine Micropaleontology, 51:1-21.

Ehrenberg, C.G. 1838. Über dem blossen Auge unsichtbare Kalkthierchen und Kieselthierschen als Hauptbestandtheile der Kreidegebirge. Bericht über die zur Bekanntmachung geeigneten Verhandlungen der Königlichen Preußischen Akademie der Wissenschaften zu Berlin, 1838:192-200.

Ehrenberg, C.G. 1839. Über die Bildung der Kreidefelsen und des Kreidemergels durch unsichtbare Organismen. Abhandlungen der Königlichen Akademie der Wissenschaften zu Berlin, 1838:60-148.

Ehrenberg, C.G. 1840. Eine, weitere Erlauterung des Organismus meherer in Berlin lebend beobachteter Polythalamien der Nordesee. Abhandlungen der Königlichen Akademie der Wissenschaften, Berlin, 1840:18-23.

Ellis, B.F. and Messina, A.R. 1942-2012. Catalogue of Foraminifera. Bulletin of the American Museum of Natural History, Micropaleontological Press.

www.micropress.org/e_m.html Accessed during 2012.

Fatela, F., Moreno, J., Moreno, F., Araújo, M., Valente, T., Antunes, C., Taborda, R., Andrade, C., and Drago, T. 2009. Environmental constraints of foraminiferal assemblages distribution across a brackish tidal marsh (Caminha, NW Portugal). Marine Micropaleontology, 70:70-88.

Fatela, F. and Silva, P. 1990. Associações actuais de foraminíferos e ostracodos no litoral a Norte de Peniche. Anais do Instituto Hidrográfico, 11:31-40.

Feyling-Hanssen, R.W. 1972. The foraminifera Elphidium excavatum (Terquem) and its variant forms. Micropaleontology, 18:337-354. 
Frontalini, F. and Coccioni, R. 2011.Benthic foraminifera as bioindicators of pollution: A review of Italian research over the last three decades. Revue de Micropaléontologie, 54:115-127.

Fursenko, A.V. 1958. Osnovnye etapy razvitiya faun foraminifer v geologicheskom proshlom. Trudy Instituta Geologicheskikh Nauk, Akademiia Nauk Belorusskoi SSR, Minsk, 1:10-29.

Galloway, J.J. 1933. A Manual of Foraminifera. Principal Press, Bloomington.

Glaessner, M.F. 1937. Die Entfaltung der Foraminiferenfamilie Buliminidae. Problemy Paleontologii, Paleontologicheskaya Laboratoriya Moskovskogo Gosudarstvennogo Universiteta, 2-3:411-422.

González, M., Ruíz, F., Baceta, J., González, E., and Muñoz, J.M. 2000. Total benthic foraminifera assemblages in the southwestern Spanish estuaries: Geobios, 34:39-51.

Haynes, J.R. 1973. Cardigan Bay recent foraminifera. Bulletin of the British Museum of Natural History (Zoology), supplement 4:1-245.

Haynes, J.R. 1981. Foraminifera. John Wiley and Sons, New York.

Hayward, B.W., Cedhagen, T., Kaminski, M., and Gross, O. 2014. World Modern Foraminifera database. Accessed through: World Register of Marine Species at www.marinespecies.org/ Consulted in 2014.

Hayward, B.W., Grenfell, H.R., Reid, C.M., and Hayward, K.A. 1999a. Recent New Zealand ShallowWater Benthic Foraminifera: Taxonomy, Ecologic Distribution, Biogeography, and Use in Paleoenvironmental Assessment. Monograph, 21, Institute of Geological and Nuclear Sciences.

Hayward, B.W., Grenfell, H.R., and Scott, D.B. 1999b. Tidal range of marsh foraminifera for determining former sea-level heights in New Zealand. New Zealand Journal of Geology and Geophysics, 42:395-413.

Hayward, B.W. and Hollis, C.J. 1994. Brackish foraminifera in New Zealand: a taxonomic and ecological review. Micropaleontology, 40:185-222.

Hayward, B.W., Hollis, C.J., and Grenfell, H.R. 1997. Recent Elphidiidae (Foraminiferida) of the SouthWest Pacific and Fossil Elphidiidae of New Zealand. Monograph 16, Institute of Geological and Nuclear Sciences.

Hayward, B.W., Holzmann, M., Grenfell, H.R., Pawlowski, J., and Triggs, C.M. 2004. Morphological distinction of molecular types in Ammonia - towards a taxonomic revision of the world's most commonly misidentified foraminifera. Marine Micropaleontology, 50:237-271.

Heron-Allan, E. and Earland, A. 1911. On the recent and fossil Foraminifera of the shore-sands of Selsey Bill, Sussex; Part VII- Supplement (Addenda and Corrigenda), Journal of Royal Microscopical Society, 31:298-343.

Heron-Allan, E. and Earland, A. 1930. Some new foraminifera from the South Atlantic, Part 3. Journal of Royal Microscopical Society, 50:38-45.
Hofker, J. 1951. The foraminifera of the Siboga Expedition, Part III. Siboga Expetitie, Monography IV, E.J. Bill, Leiden.

Hofker, J. 1960. Foraminiferen aus dem Golf von Neapel. Paläontologische Zeitschrift, 34:233-262.

Holzmann, M. and Pawlowski, J. 1997. Molecular, morphological and ecological evidence for species recognition in Ammonia beccarii (Foraminifera). Journal of Foraminiferal Research, 27:311-318.

Holzmann, M., Piller, W.E., Zaninetti, L., Fenner, R., Martini, R., Serandrei-Barbero, R., and Pawlowski, J. 1998. Molecular versus morphologic variability in Ammonia spp. (foraminifera, protozoa) from the Lagoon of Venice, Italy. Revue de Micropaléontologie, 41:59-69.

Horton, B. and Murray, J. 2007. The roles of elevation and salinity as primary controls on living foraminiferal distributions: Cowpen Marsh, Tees Estuary, UK. Marine Micropaleontology, 63:169-186.

Horton, B., Whittaker, J., Thomson, K., Hardbattle, M., Kemp, A., Woodroffe, S., and Wright, M. 2005.The development of a modern foraminiferal data set for sea-level reconstructions, Wakatobi Marine National Park, southeast Sulawesi, Indonesia. Journal of Foraminiferal Research, 35:1-14.

Hurlbert, S.H. 1984. Pseudoreplication and the design of ecological field experiments. Ecological Monographs, 54:187-211.

ICNB, 2007. Reserva Natural, Sapal de Castro Marim e Vila Real de Sto António:

portal.icnb.pt/ICNPortal/vPT2007 (accessed 2 December 2009)

I.H. - Instituto Hidrográfico, 2011. Tabela de Marés, Cap. 3. Lisboa.

Javaux, E.J. and Scott, D.B. 2003. Illustration of modern benthic foraminifera from Bermuda and remarks on distribution in other subtropical/tropical areas. Palaeontologia Electronica 6(4), 29 pp, 2.1MB; palaeo-electronica.org/2003_1/benthic/ issue 1 03.htm

Jones, R. $\bar{W}$. 1994. The Challenger Foraminifera. The Natural History Museum of London. Oxford University Press.

Kornfeld, M.M. 1931. Recent littoral Foraminifera from Texas and Louisiana, Stanford University, Contributions from the Department of Geology, Palo Alto, 1:77-93.

Lamarck, J.B. 1804. Suite des mémoires sur les fossils des environs de Paris. Annales Muséum National d'Histoire Naturelle, 5:179-188.

Langer, M.R. 2000. Comparative molecular analysis of small-subunit ribosomal 18s DNA sequences from Haynesina germanica (Ehrenberg, 1840), a common intertidal foraminifera from the North Sea. Neues Jahrbuch für Geologie und Paläontologie, Monatshefte, 11:641-650. 
Langer, M.R. and Leppig, U. 2000. Molecular phylogenetic status of Ammonia catesbyana (D'Orbigny, 1839), an intertidal foraminifer from the North Sea. Neues Jahrbuch für Geologie und Paläontologie, Monatshefte, 9:545-556.

Langer, M.R. and Schmidt-Sinns, J. 2006. Architecture, ontogenetic development and biogeographic distribution of Cribroelphidium mirum, a new species of benthic foraminifera from South Africa and Namibia (SAtlantic Ocean). Neues Jahrbuch für Geologie und Paläontologie, Monatshefte, 11:667-682.

Lankester, E.R. 1885. Protozoa, p. 831-865. In Baynes, T.S. (ed.), The Encyclopedia Britannica, 9th ed. Volume 19. J.M. Stoddard Co., Ltd. Philadelphia, Pennsylvania.

Le Calvez, J. and Le Clavez, Y. 1951. Contribution à l'étude de foraminifères des eaux saumâtres: I. Étangs de Canet et de Salses. Vie and Millieu, 2:237245.

Lee, J. 1990. Diatoms, or their chloroplasts, as endosymbiotic partners for foraminifera, p. 21-36. In Proceedings of the $11^{\text {th }}$ International Diatom Symposium, San Francisco, California.

Leorri, E. and Cearreta, A. 2004. Holocene environmental development of the Bilbao estuary, northern Spain: sequence stratigraphy and foraminiferal interpretation. Marine Micropaleontology, 51:75-94.

Leorri, E., Gehrels, R., Horton, B., Fatela, F., and Cearreta, A. 2010. Distribution of foraminifera in salt marshes along the Atlantic coast of SW Europe: Tools to reconstruct past sea-level variations. Quaternary International, 221:104-115.

Leps, J. and Smilauer, P. 2003. Multivariate Analysis of Ecological Data Using CANOCO. Cambridge University Press, New York.

Lévy, A. 1966. Contribution à l'étude écologique et micropaléontologique de quelques Elphidium (Foraminifères) du Roussillon. Description d'une nouvelle espèce: Elphidium cuvillieri n.sp. Vie et milieu, t. 17, fasc, I.A., p. 1-8.

Lévy, A., Mathieu, R., Poignant, A., Rosset-Molinier and Rouvillois, A. 1974. Les représentants des Ammodiscacea, Lituolacea, Nodosariacea, Buliminacea (Foraminifères) dans les sables des plages de Dunkerque. Remarques sur les espèces signalées par 0 . Terquem. Revue de Micropaléontologie, 17:127-133.

Lévy, A., Mathieu, R., Poignant, A., Rosset-Molinier, M., Ubaldo, M., and Ambroise, D. 1993. Recent foraminifera from de continental margin of Portugal. Micropaleontology, 39:75-87.

Lévy, A., Mathieu, R., Poignant, A., Rosset-Moulinier, M., Ubaldo, M., and Lebreiro, S. 1995. Foraminiferes Actuels de la Marge Continentale Portugaise Inventaire et Distribuition. Memórias do Instituto Geológico e Mineiro, Lisboa, 32:1-116.

Linné, C. 1758. Systema Naturae per Regna Tria Naturae, Secundum Classes, Ordines, Genera, Species, cum Characteribus, Differentiis, Synonymis, Locis, 1, 10th edition. L. Salvii, Holmiae (Stockholm).
Loeblich, A.R. and Tappan, H. 1953. Studies of Artic Foraminifera. Smithsonian Miscellaneous Collections, 121:1-142.

Loeblich, A.R. and Tappan, H. 1984. Suprageneric classification of the Foraminiferida (Protozoa). Micropaleontology, 30:1-70

Loeblich, A.R. and Tappan, H. 1986. Some new and revised genera and families of hyaline calcareous Foraminiferida (Protozoa). Transactions of the American Microscopical Society, 105:239-265.

Loeblich, A.R. and Tappan, H. 1987. Foraminiferal Genera and their Classification. Van Nostrand Reinhold, New York, vol. 1 and 2.

Lowe, J.J. and Walker, M.J.C. 1997. Reconstructing Quaternary Environments. Longman, $2^{\mathrm{a}}$ edition, England.

M.A. - Ministério do Ambiente (Portuguese Ministry of the Environment) 1999. Plano de Bacia Hidrográfica do Rio Guadiana - $1^{\text {a }}$ fase, Análise e Diagnóstico da Situação Actual, volume III.

Martins, M.V., Frontalini, F., Laut, L., Silva, F., Moreno, J., Sousa S., Zaaboub, N., El Bour, M., and Rocha F. 2014. Foraminiferal biotopes and their distribution control in Ria de Aveiro (Portugal): a multiproxy approach. Environmental Monitoring and Assessment, DOI 10.1007/s10661-014-4052-7

Martins, V., Dubert, J., Jouanneau, J.-M., Weber, O., da Silva, E.F., Patinha, C., Alveirinho Dias, J.M., and Rocha, F. 2007. A multiproxy approach of the Holocene evolution of shelf-slope circulation on the NW Iberian Continental Shelf. Marine Geology, 239:1-18.

Martins, V., Frontalini, F., Tramonte, K., Figueira, R., Miranda, P., Sequeira, C., Fernández-Fernández, S., Dias, J., Yamashita, C., Renó, R., Laut, L., Silva, F., Rodrigues, M., Bernardes, C., Nagai, R., Sousa, S., Mahiques, M., Rubio, B., Bernabeu, A., Rey, D., and Rocha, F. 2013. Assessment of the health quality of Ria de Aveiro (Portugal): Heavy metals and benthic foraminifera. Marine Pollution Bulletin, 70:18-33.

Martins, V. and Gomes, V. 2004. Foraminíferos da Margem Continental NW Ibérica, Sistemática, Ecologia e Distribuição. Agenda Comum - Comunicação Lda.

Martins, V., Jouanneau, J.-M., Weber, O., and Rocha, F. 2006. Tracing the late Holocene evolution of the NW Iberian upwelling system. Marine Micropaleontology, 59:35-55.

Martins, V., Silva, E., Sequeira, C., Rocha, F., and Duarte, A. 2010. Evaluation of the ecological effects of heavy metals on the assemblages of benthic foraminifera of the canals of Aveiro (Portugal). Estuarine, Coastal and Shelf Science, 87:293-304.

Mendes, I. 2010. Benthic Foraminifera as Paleo-Environmental Indicators in the Northern Gulf of Cadiz. Unpublished Ph.D. thesis, Universidade do Algarve, Portugal.

Mendes, I., Dias, J.A., Schönfeld, J., and Ferreira, Ó. 2012. Distribution of living benthic foraminifera on the northern Gulf of Cadiz continetal shelf. Journal of Foraminiferal Research, 42:18-38. 
Mendes, I., Gonzalez, R., Dias, J.M.A., Lobo, F., and Martins, V. 2004. Factors influencing recent benthic foraminifera distribution on the Guadiana shelf (Southwestern Iberia). Marine Micropaleontology, 51:171-192.

Mikhalevich, V.I. 1980. Novoe podsemeystvo Discammininae Mikhalevich, subfam. n. (Lituolidae, Foraminifera) [The new subfamily Discammininae Mikhalevich, subfam. n. (Lituolidae, Foraminifera)]. In Investigations of the fauna of the seas, XXV (XXXIII), News in the systematics of the sea invertebrates. Leningrad: Zoologichesky Institut Rossijskoy Academii Nauk, 25(33):5-7. (In Russian)

Milker, Y. and Schmiedl, G. 2012. A taxonomic guide to modern benthic shelf foraminifera of the western Mediterranean Sea. Palaeontologia electronica, 5.2.16A, $134 \mathrm{pp}, 21.9 \mathrm{MB}$;

palaeo-electronica.org/content/2012-issue-2-articles/ 223-taxonomy-foraminifera

Miller, A.A., Scott, D.B., and Medioli, F. 1982. Elphidium excavatum (Terquem): Ecophenotypic versus subspecific variation. Journal of Foraminiferal Research, 12:116-144.

Montagu, G. 1808. Testacea Britannica, or Natural History of British Shells, marine, land, and fresh-water, including the most minute. Supplement, S. Woolmer, Exeter.

Morales, J.A., Delgado, I., and Gutierrez-Mas, J.M. 2006. Sedimentary characterization of bed types along the Guadiana estuary (SW Europe) before the construction of the Alqueva dam. Estuarine, Coastal and Shelf Science, 70:117-131.

Moreno, J., Fatela, F., Andrade, C., Cascalho, J., Moreno, F., and Drago, T. 2005. Living foraminiferal assemblages from the Minho and Coura Estuaries (Northern Portugal): A stressful environment. Thalassas, 21:1-28.

Murray, J. 1971. An Atlas of British Recent Foraminiferids. Heinemann Educational Books, London.

Murray, J. 2003. An illustraded guide to the benthic foraminifera of the Hebridean Shelf, West of Scotland, with notes on their mode of life. Palaeontologia Electronica 5.1: 31 pp., 1.4MB;

palaeo-electronica.org/paleo/2002_2/guide/ issue 2 02.htm

Murray, J. 2007. Biodiversity of living benthic foraminifera: How many species are there? Marine Micropaleontology, 64:163-176.

Murray, J. and Alve, E. 1999. Taphonomic experiments on marginal marine foraminiferal assemblages: how much ecological information is preserved? Palaeogeography, Palaeoclimatology, Palaeoecology, 149:183-197.

Murray, J. and Alve, E. 2011. The distribution of agglutinated foraminifera in NW European seas: Baseline data for the interpretation of fossil assemblages. Palaeontologia Electronica 14.2.14A: 41 pp., 6.08MB;

palaeo-electronica.org/2011_2/248/index.html
Natland, M.L. 1938. New species of foraminifera from off the West Coast of North America and from the later Tertiary of the Los Angeles Basin. University of California, Scripps Institution of Oceanography Bulletin, Technical Series, 4(5):137-164.

Oliveira, A., Fortunato, A., and Pinto, L. 2006. Modelling the hydrodynamics and the fate of passive and active organisms in the Guadiana Estuary. Estuarine, Coastal and Shelf Science, 70:76-84.

Parker, F.L. 1952. Foraminiferal distribution in the Long Island Sound - Buzzards Bay area. Bulletin of the Museum of Comparative Zoology, at Harvard College, 106(10):1-491.

Parker, F.L. and Athearn, W.D. 1959. Ecology of marsh foraminifera in Poponesset Bay, Massachusetts. Journal of Paleontology, 33:333-343.

Parker, F.L., Phleger, F.B., and Pierson, J.F. 1953. Ecology of foraminifera from San Antonio Bay and environs, southwest Texas. Cushman Foundation for Foraminiferal Research Special Publication, 2:1-75.

Parker, W.K. and Jones, T. 1859. On the nomenclature of the foraminifera, Part. 2, On the species enumerated by Walker and Montagu. Annals and Magazine of Natural History, 4:333-351.

Parker, W.K. and Jones, T.R. 1865. On some foraminifera from the North Atlantic and Arctic Oceans, including Davis Strait and Baffin's Bay. Philosophic Transactions of the Royal Society of London, 155:325-441.

Patterson, R.T. 1990. Intertidal benthic foraminiferal biofacies on the Fraser River Delta, British Columbia: Modern distribution and paleoecological importance. Micropaleontology, 36:229-244.

Pawlowski, J. 2000. Introduction to the molecular systematics of foraminifera. Micropaleontology, 46:1-12.

Pawlowski, J., Bolivar, I., Fahrni, J.F., and Zaninetti, L. 1994. Taxonomic identification of foraminifera using ribosomal DNA sequences. Micropaleontology, 40:373-377.

Pawlowski, J., Bolivar, I., Fahrni, J.F., and Zaninetti, L. 1995. DNA analysis of "Ammonia beccari" morphotypes: one or more species? Marine Micropaleontology, 26:171-178.

Pawlowski, J. and Holzmann, M. 2010-2014. ForamBarcoding - Molecular Database of Foraminifera. forambarcoding.unige.ch/. Consulted during 2014.

Pawlowski, J., Holzmann, M., Bernay, C., Fahrni, J., Gooday, J., Cedhagen, T., Habura, A., and Bowser, S.S. 2003. The evolution of early Foraminifera. PNAS, 100:11494-11498.

Petrucci, F., Medioli, F.S., Scott, D.B., Pianetti, A., and Cavazzini, R. 1983. Evaluation of the usefulness of foraminifera as sea-level indicators in the Venice Lagoon (N. Italy): Acta-Naturalia de 'L'Ateneo Parmense", 19:63-77.

Phleger, F.B. and Parker, F.L. 1952. Ecology of foraminifera, northwest Gulf of Mexico. Part 2. Foraminifera species. Geological Society of America Memoir, 46:1-64. 
Ramsar, Scientific and Technical Review Panel, 2013. The List of Wetlands of

International Importance. Ramsar Secretariat, Gland, Switzerland. http://ramsar.wetlands.org/Database/ Searchforsites/tabid/765/Default.aspx (accessed January 2013)

Redois, F. and Debenay, J.-P. 1996. Influence du confinement sur la répartition des foraminiferes benthiques: exemple de l'estran d'une ria mésotidale de Bretagne Méridionale. Revue de Paléobiologie, 15:243-260.

Reiss, Z. 1963. Reclassification of perforate foraminifera. Bulletin of the Geological Survey of Israel, 35:1-111.

Reuss, A.E. 1850. Neue Foraminiferen aus den Schichten des österreichischen Tertiärbeckens. Denkschriften der mathematisch-naturwissenschaftlichen Classe der kaiserlichen Akademie der Wissenschaften (1849), 1:360-395.

Reuss, A.E. 1862. Entwurf einer systematischen Zusammenstellung der Foraminiferen. Sitzungsberichte der Kaiserliche Akademie der Wissenschaften in Wien, Mathematisch-Naturwissenschaftliche Klasse, 44:355-396.

Rhumbler, L. 1913. Die foraminiferen (Thalamorphoren) der Plankton-Expedition: Ergebnisse der PlanktonExpedition der Humboldt-Stiftung, 3, Lief. C.

Rocha, C., Galvão, H., and Barbosa, A. 2002. Role of transient silicon limitation in the development of cyanobacteria blooms in the Guadiana estuary, southwestern Iberia. Marine Ecology Progress Series, 228:35-45.

Ruiz, F.M., González, M.L., and Morales, J.A. 1996. Distribución y Ecología de los Foraminíferos y Ostrácodos Actuales del Estuario Mesomareal del Río Guadiana (SO España). Geobios, 29:513-528.

Ruiz, F.M., González, M.L., Pendón, J.G., Abad, M., Olías, M., and Muñoz, J.M. 2005. Correlation between foraminifera and sedimentary environments in recent estuaries of Southwestern Spain: Applications to Holocene reconstructions. Quaternary International, 140:21-36.

Saunders, J.B. 1957. Trochamminidae and certain Lituolidae (foraminifera) from the recent brackish-water sediments of Trinidad, British West Indies. Smithsonian Miscellaneous Collections, 134(5):1-20.

Saunders, J.B. 1961. Helenina Saunders, new name for the foraminiferal genus Helenia Saunders, 1957, non Helenia Walcott, 1880. Contributions of the Cushman Foundation for Foraminiferal Research, 12:1-148.

Schultze, M.S. 1854. Über den Organismus der Polythalamien (Foraminiferen) nebst Bemerkungen über die Rhizopoden im Allgemeinen. Engelmann, W., Leipzig.

Schwager, C. 1877. Quadro del proposto sistema di classificazione dei foraminiferi con guscio. Bolletino R. Comitato Geologico d'Italia, 8:18-27.
Scott, D.B. 1976a. Quantitative studies of marsh foraminiferal patterns in southern California and their application to Holocenic stratigraphic problems, p.153-170. In Pelletier, B.R. and Schafer, C.T. (eds.), First International Symposium on Benthonic Foraminifera of Continental Margins, Part A, Ecology and Biology, Maritime Sediments Special Publication.

Scott, D.B. 1976b. Brackish-water foraminifera from southern California and description of Polysaccammina ipohalina n. gen., n. sp. Journal of Foraminiferal Research, 6:312-321.

Scott, D.B., Hasegawa, S., Saito, T., Ito, K., and Collins, E. 1995. Marsh foraminiferal and vegetation distributions in Nemuro Bay wetland areas, eastern Hokkaido. Transactions and Proceedings of the Palaeontological Society of Japan, 80:282-295.

Scott, D.B. and Hermelin, J.O.R. 1993. A Device for Precision Splitting of Micropaleontological Samples in Liquid Suspension. Journal of Paleontology, 67:151154.

Scott, D.B. and Medioli, F.S. 1978. Vertical zonation of marsh foraminifera as accurate indicators of former sea-level. Nature, 272:538-541.

Scott, D.B. and Medioli, F.S. 1980. Quantitative studies of marsh foraminiferal distributions in Nova Scotia: their implications for the study of sea-level changes. Cushman Foundation for Foraminiferal Research, Special Publication, 17.

Scott, D.B., Piper, D., and Panagos, A. 1979. Recent salt marsh and intertidal mudflat Foraminifera from the western coast of Greece. Rivista Italiana di Paleontologia, 85:243-266.

Scott, D.B., Schafer, C.T., and Medioli, F.S. 1980. Eastern Canadian Estuarine Foraminifera: a Framework for Comparison. Journal of Foraminiferal Research, 10:205-234.

Scott, D.B., Schafer, C.T., and Medioli, F.S. 2001. Monitoring in Coastal Environments using Foraminifera and Thecamoebian Indicators. Cambridge University Press, Cambridge.

Scott, D.B., Schnack, E.J., Ferrero, L., Espinosa, M., and Barbosa, C.F. 1990. Recent Marsh Foraminifera from the East Coast of South America: Comparison to the Northern Hemisphere, p. 717-738. In Hemleben et al. (eds.), Paleoecology, Biostratigraphy, Paleooceanography, and Taxonomy of agglutinated foraminifera, Kluwer Academic Publishers, Netherlands, Proceedings of NATO ASI/Series C.

Scott, D.B., Suter, J., and Kosters, E. 1991. Marsh foraminifera and arcellaceans of the lower Mississippi Delta: Controls on spatial distributions. Micropaleontology, 37:373-392.

Sen Gupta, B.K. 1999. Foraminifera in marginal marine environments, p. 141-160. In Sen Gupta, B.K. (ed.), Modern Foraminifera. Kluwer Academic Publishers, London. 
Serandrei-Barbero, R., Carbognin, L., Taroni, G., and Cova, E. 1999. Distribution of recent benthic foraminifera in the southern basin of the Venice Lagoon (Italy): Statistical evaluation of taxa significance. Micropaleontology, 45:99-111.

Simonson, W. 2007. Vegetation mapping in Guadiana Estuary, p. 65-68. In A Rocha Portugal Observatory Report for 2005-2006. Associação A Rocha, Portimão, Portugal.

Suleymanov, I.S. 1959. O novom rodye i vidye foraminifer iz sem. Ammodiscidae (on a new genus and species of foraminifera from the family Ammodiscidae). Doklady Akademii Nauk UzSSR, 7:9-20. (In Russian)

Terquem, O. 1875. Essai sur le classement des animaux qui vivent sur la plage et dans les environs de Dunquerque, Memoirs de la Society Dunkerquoise (1876), 19:405-447.

Thomas, E. and Varekamp, J.C. 1991. Paleo-environmental analysis of marsh sequences (Clinton, Connecticut): Evidence for punctuated rise in relative sea level during the latest Holocene. Journal of Coastal Research, 11:125-158.

Todd, R. and Brönnimann, P. 1957. Recent foraminifera and thecamoebian from the eastern Gulf of Paria. Cushman Foundation for Foraminiferal Research, Special Publication, 3.

Todd, R. and Low, D. 1981. Marine Flora and Fauna of the Northeastern United States. Protozoa: Sarcodina: Benthic Foraminifera. NOAA Technical Report NMFS Circular 439:1-50.

Van Voorthuysen, J.H. 1957. Foraminiferen aus dem Eemien (Riss-Würm-Interglazial) in der Bohrung Amersfoort I (Locus typicus). Mededelingen van de Geologische Stichting, Haarlem, nieuwe ser, 11:2739.
Varekamp, J.C., Thomas, E., and Van de Plassche, O. 1992. Relative sea-level rise and climate change over the last 1500 years. Global Change, 4:293-304.

Villanueva, P.G., Canudo, J.I.S., and Cervera, J.L.C. 1999. Los Foraminíferos Bentónico Recientes de la Superfamilia Miliolacea Ehrenberg, 1836 en los Sedimentos Superficiales del Margen Septentrional del Golfo de Cádiz. Revista Española de Micropaleontología, 31:99-122.

Walker, G. and Jacob, E. 1798. Adams' Essays on the Microscope, p. 629-645. In Kanmacher, F. (ed.), DilIon and Keating Publications, London.

Walton, W. and Sloan, B. 1990. The genus Ammonia Brünnich, 1772: its geographic distribution and morphological variability. Journal of Foraminiferal Research, 20:128-156.

Warren, A.D. 1957. Foraminifera of the Buras-Scofield Bayou region, southeast Louisiana. Contributions of the Cushman Foundation for Foraminiferal Research, 8:29-40.

Wennrich, V., Meng, S., and Schmiedl, G. 2007. Foraminifers from Holocene sediments of two inland brackish lakes in Central Germany. Journal of Foraminiferal Research, 37:318-326.

Williamson, W.C. 1858. On the Recent Foraminifera of Great Britain. Ray Society, London.

Yassini, I. and Jones, B.G. 1995. Foraminiferida and Ostracoda from Estuarine and Shelf Environments on the Southeastern Coast of Australia. University of Wollongong Press, Australia.

Zaninetti, L., Brönnimann, P., Beurlen, G., and Moura, J.A. 1977. La mangrove de Guaratiba et la baie de Sepetiba, état de Rio de Janeiro, Brésil: Foraminifères et écologie. Archives des Sciences de Genève, 30:161-178. 


\section{APPENDIX}

TABLE 1. Table 1 - Spatial data of study sites.

\begin{tabular}{|c|c|c|c|c|c|c|}
\hline \multirow[b]{2}{*}{ Place } & \multirow[b]{2}{*}{ Sample } & \multicolumn{3}{|c|}{ Datum 73} & \multicolumn{2}{|c|}{ WGS 84} \\
\hline & & Eastings & Northings & Elev MSL & Latitude & Longitude \\
\hline Laranjeiras & LAR & 59841.474 & -251196.821 & 0.311 & $37^{\circ} 24^{\prime} 12.28 " \mathrm{~N}$ & $7^{\circ} 27^{\prime} 26.09 " \mathrm{~W}$ \\
\hline Foz de Odeleite & $\mathrm{FO}$ & 60808.447 & -256955.96 & 0.334 & $37^{\circ} 21^{\prime} 5.26 " \mathrm{~N}$ & $7^{\circ} 26^{\prime} 48.47^{\prime \prime W}$ \\
\hline Almada d'Ouro & Aouro & 61149.393 & -261793.396 & 0.532 & $37^{\circ} 18^{\prime} 28.28 " \mathrm{~N}$ & $7^{\circ} 26^{\prime} 36.06 " \mathrm{~W}$ \\
\hline \multirow[t]{3}{*}{ Foz do Beliche } & FB1 & 61922.506 & -267062 & 1.432 & $37^{\circ} 15^{\prime} 37.211^{\prime \prime N}$ & $7^{\circ} 26^{\prime} 6.24 " \mathrm{~W}$ \\
\hline & FB2 & 61924.614 & -267057 & 0.752 & $37^{\circ} 15^{\prime} 37.38^{\prime \prime N} \mathrm{~N}$ & $7^{\circ} 26^{\prime} 6.15^{\prime \prime} \mathrm{W}$ \\
\hline & FB3 & 61927.302 & -267051 & 0.471 & $37^{\circ} 15^{\prime} 37.57 " \mathrm{~N}$ & $7^{\circ} 26^{\prime} 6.04 " \mathrm{~W}$ \\
\hline \multirow[t]{4}{*}{ Ponte Internacional } & PI1 & 62974.271 & -269471.977 & 1.188 & $37^{\circ} 14^{\prime} 18.79^{\prime \prime} \mathrm{N}$ & $7^{\circ} 25^{\prime} 24.29 " \mathrm{~W}$ \\
\hline & $\mathrm{PI} 2$ & 62997.536 & -269452.581 & 1.198 & $37^{\circ} 14^{\prime} 19.42 " \mathrm{~N}$ & $7^{\circ} 25^{\prime} 23.34 " \mathrm{~W}$ \\
\hline & $\mathrm{PI} 3$ & 63006.818 & -269442.632 & 0.614 & $37^{\circ} 14^{\prime} 19.74 " \mathrm{~N}$ & $7^{\circ} 25^{\prime} 22.97 " \mathrm{~W}$ \\
\hline & $\mathrm{PI} 4$ & 63012.253 & -269438.821 & 0.011 & $37^{\circ} 14^{\prime} 19.86 " \mathrm{~N}$ & $7^{\circ} 25^{\prime} 22.74 " \mathrm{~W}$ \\
\hline Sapal de Castro Marim & SCM & 59401.402 & -272673.316 & 1.960 & $37^{\circ} 12^{\prime} 35.80 " \mathrm{~N}$ & $7^{\circ} 27^{\prime} 50.15 " \mathrm{~W}$ \\
\hline \multirow[t]{3}{*}{ Lezíria } & LEZ1 & 61394.114 & -272397.855 & 1.317 & $37^{\circ} 12^{\prime} 44.28 " \mathrm{~N}$ & $7^{\circ} 26^{\prime} 29.26 " \mathrm{~W}$ \\
\hline & LEZ2 & 61390.198 & -272388.367 & 1.062 & $37^{\circ} 12^{\prime} 44.58 " \mathrm{~N}$ & $7^{\circ} 26^{\prime} 29.41 " \mathrm{~W}$ \\
\hline & LEZ3 & 61391.183 & -272387.306 & 0.202 & $37^{\circ} 12^{\prime} 44.62 " \mathrm{~N}$ & $7^{\circ} 26^{\prime} 29.37 " \mathrm{~W}$ \\
\hline \multirow[t]{4}{*}{ Vila Real da Santo António } & VRSA1 & 63557.17 & -272825.6 & 1.210 & $37^{\circ} 12^{\prime} 29.88^{\prime \prime N}$ & $7^{\circ} 25^{\prime} 1.68 " \mathrm{~W}$ \\
\hline & VRSA2 & 63560.61 & -272836.35 & 1.030 & $37^{\circ} 12^{\prime} 29.95 " \mathrm{~N}$ & $7^{\circ} 25^{\prime} 1.23 " \mathrm{~W}$ \\
\hline & VRSA3 & 63571.94 & -272863.74 & 0.290 & $37^{\circ} 12^{\prime} 30.22 " \mathrm{~N}$ & $7^{\circ} 25^{\prime} 0.07^{\prime \prime W}$ \\
\hline & VRSA4 & 63589.81 & -272904.11 & -0.470 & $37^{\circ} 12^{\prime} 30.65^{\prime \prime N}$ & $7^{\circ} 24^{\prime} 58.37^{\prime \prime W}$ \\
\hline Espanha ETAR & $\mathrm{EE}$ & 64604.906 & -274266.784 & -0.743 & $37^{\circ} 11^{\prime} 42.88^{\prime \prime} \mathrm{N}$ & $7^{\circ} 24^{\prime} 19.63 " \mathrm{~W}$ \\
\hline \multirow[t]{3}{*}{ Espanha } & E1 & 64684.93 & -274521.467 & 0.574 & $37^{\circ} 11^{\prime} 34.60 " \mathrm{~N}$ & $7^{\circ} 24^{\prime} 16.47^{\prime \prime W}$ \\
\hline & E2 & 64677.255 & -274521.922 & -0.066 & $37^{\circ} 11^{\prime} 34.58 " \mathrm{~N}$ & $7^{\circ} 24^{\prime} 16.78 " \mathrm{~W}$ \\
\hline & E3 & 64637.258 & -274532.308 & -0.743 & $37^{\circ} 11^{\prime} 34.26 " \mathrm{~N}$ & $7^{\circ} 24^{\prime} 18.41 " \mathrm{~W}$ \\
\hline \multirow[t]{3}{*}{ Lagoa } & LG1 & 64513.526 & -276692.511 & 0.397 & $37^{\circ} 10^{\prime} 24.26 " \mathrm{~N}$ & $7^{\circ} 24^{\prime} 24.06 " \mathrm{~W}$ \\
\hline & LG2 & 64509.007 & -276696.394 & 0.167 & $37^{\circ} 10^{\prime} 24.14 " \mathrm{~N}$ & $7^{\circ} 24 ' 24.24 " \mathrm{~W}$ \\
\hline & LG3 & 64506.052 & -276699.545 & -0.090 & $37^{\circ} 10^{\prime} 24.03^{\prime \prime N}$ & $7^{\circ} 24^{\prime} 24.36 " \mathrm{~W}$ \\
\hline
\end{tabular}

TABLE 2. Absolute and relative frequencies of living foraminifera in winter samples. In gray - samples with less than 48 living individuals (presented in PDF format online at palaeo-electronica.org/content/2015/269-512/ 1130-estuarine-forams-from-iberia).
TABLE 3. Absolute and relative frequencies of living foraminifera in summer samples. In gray - samples with less than 48 living individuals. (presented in PDF format online at palaeo-electronica.org/content/2015/269-512/ 1130-estuarine-forams-from-iberia) 